San Jose State University

SJSU ScholarWorks

Master's Projects

Master's Theses and Graduate Research

$5-2019$

\title{
Food Scrapping Programs and Smart Practices for SB 1383 Compliance in Ten Selected Bay Area Cities
}

Alia Rizvi Haque

San Jose State University

Follow this and additional works at: https://scholarworks.sjsu.edu/etd_projects

Part of the Environmental Policy Commons, Other Public Affairs, Public Policy and Public Administration Commons, and the Public Administration Commons

\section{Recommended Citation}

Haque, Alia Rizvi, "Food Scrapping Programs and Smart Practices for SB 1383 Compliance in Ten Selected Bay Area Cities" (2019). Master's Projects. 661.

DOI: https://doi.org/10.31979/etd.dd4b-9fsb

https://scholarworks.sjsu.edu/etd_projects/661

This Master's Project is brought to you for free and open access by the Master's Theses and Graduate Research at SJSU ScholarWorks. It has been accepted for inclusion in Master's Projects by an authorized administrator of SJSU ScholarWorks. For more information, please contact scholarworks@sjsu.edu. 
Food Scrapping Programs and Smart Practices for SB 1383 Compliance in Ten Selected Bay Area Cities

by

Alia Rizvi Haque

\begin{abstract}
A Thesis Quality Research Project
Submitted in Partial Fulfillment

of the Requirements for the

Masters of Public Administration
\end{abstract}

Professor Frances Edwards, Ph.D.

Advisor

The Graduate School

San José State University

May, 2019 


\section{Table of Contents}

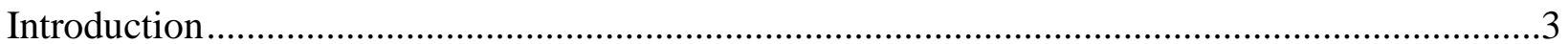

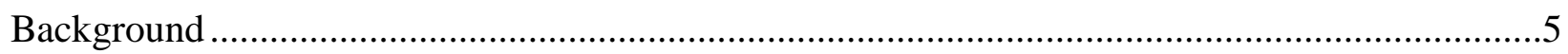

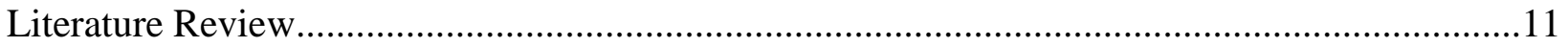

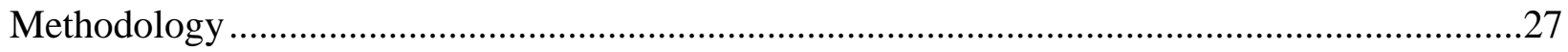

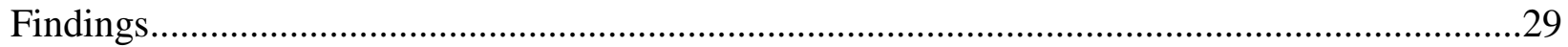

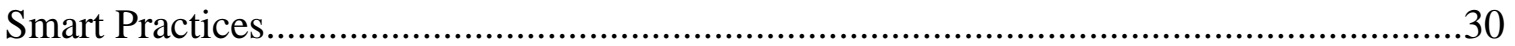

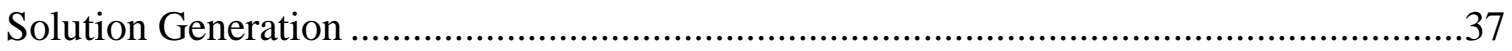

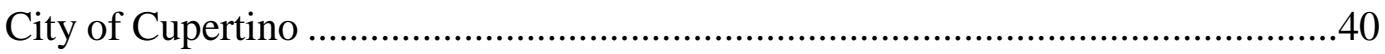

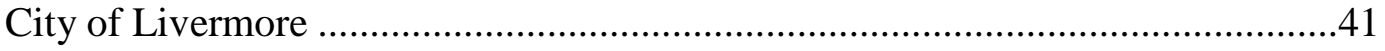

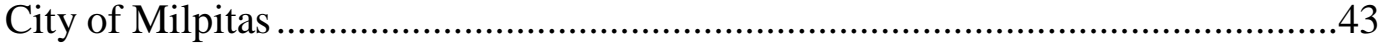

City of Morgan Hill .......................................................................................... 44

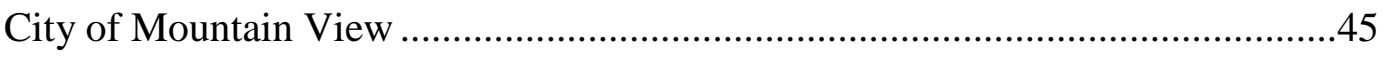

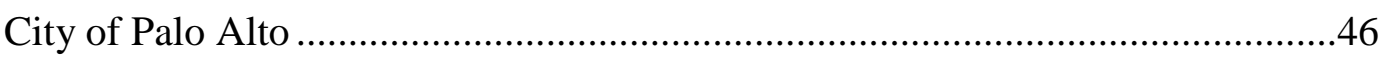

County and City of San Francisco .........................................................................49

City of San Jose ...........................................................................................

City of Santa Clara...........................................................................................54

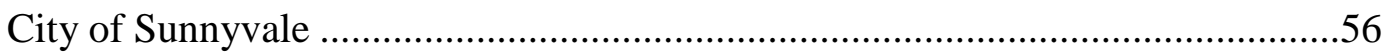

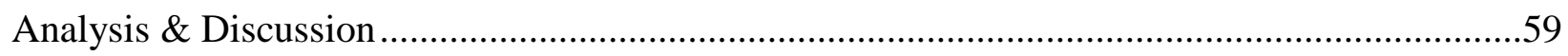

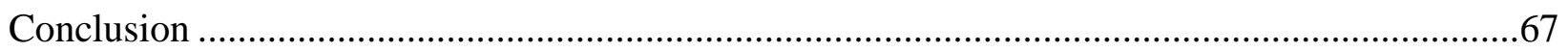

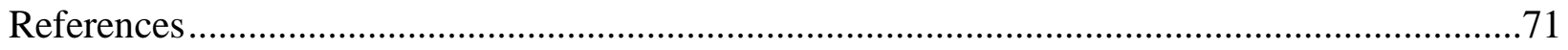

Appendix A: EPA Food Recovery Hierarchy...............................................................................83

Appendix B: City of Milpitas Garbage Cart Rates ..................................................................... 


\section{INTRODUCTION}

\section{The Problem}

Thirty five percent of landfill waste in California is made up of organic waste, and 18\% of landfill waste is made up of food scraps (City of Santa Clara [CSC], 2019). The buildup and decomposition of food scraps at landfills produce methane (CSC, 2019), a pollutant that heats up the atmosphere thousands of times more than carbon dioxide (California Air Resources Board [CARB], 2018). Senate Bill (SB) 1383 is meant to mitigate pollution by requiring the state to reduce organic waste in its landfills to reduce methane production (CARB, 2018). The bill requires the state to reduce organic waste in landfills to $50 \%$ of 2014 levels by 2020 , and to $25 \%$ by 2025 (California Legislative Information [CLI], 2016).

CARB was mandated to implement a strategy to achieve these goals by January 1, 2018. The Department of Resources Recycling and Recovery (DRRR), also known as CalRecycle, is required to analyze the progress that the state and local governments and the waste management sector have made towards achieving those goals by July 1, 2020. It was the intent of the legislation that local governments would be in charge of diverting organic waste from landfills. Cities are addressing these goals by creating and implementing Residential Food Scrap Programs (RFSP), which are programs that target residents (as opposed to commercial or businesses) for food scraps collection.

\section{Research Question and Purpose}

This research project attempted to determine how San Francisco and nine cities in Alameda and Santa Clara Counties complied with SB 1383 through food scrapping programs, and to determine the best practices of such programs. The purpose of this project was to give local governments insight and guidance as they create and implement programs to comply with SB 1383. 


\section{BACKGROUND}

The entire waste system in the U.S. has seen dramatic changes since the 1980s when the Environmental Protection Agency (EPA) issued stricter requirements on landfill construction. With the EPA's actions and rising landfill tipping costs (the cost of dumping or disposing waste at landfills), people started to believe that landfill space was becoming scarce and that a landfill crisis was imminent. This sparked two national trends. Customers began being charged for the number and size of bins they used for general waste disposal; through this system, recycling led to lower fees. The other trend was the increasing use of curbside recycling programs (Jenkins, Martinez, Palmer, \& Podolsky, 2003). Woodbury, New Jersey was the first city to mandate recycling in 1980 (Goodyear, 2018). The number of recycling programs in the U.S. has significantly grown since the 1980s. In 1988 there were only 1000 curbside recycling programs (Jenkins et al., 2003). In 2011 the EPA estimated that the U.S. had 9,800 curbside recycling programs covering roughly 70\% of the population (Desilver, 2016).

People have been composting in the U.S. since before state or county law required it. For example, Berkeley, California has encouraged its residents to compost since the 1970s. Most curbside programs began after California’s Waste Management Act (WMA) of 1989, which required municipalities to divert $50 \%$ of their landfill waste by 2000 . To comply with the WMA, San Francisco and Berkeley analyzed their waste, which showed that organics were a significant component; the cities determined that reaching waste diversion goals would be unlikely unless they addressed organic waste. Both cities then started curbside compostable programs to divert organic waste. Food scrapping collection started relatively later; for example, Berkeley did not include food scrapping as part of their composting program until 2007 (Layzer and Schulman, 
2014). As of 2011, there were roughly 189 food scrapping programs in the U.S. (Freeman \& Skumatz, 2011a); the number of such programs only increased to 198 in 2014 (Yepsen, 2015). Food Scrapping, Composting, \& Zero Waste

Composting and zero waste programs were researched in addition to RFSPs because such programs had food scrapping components that may be useful in determining best practices. Communities may question the need for a separate RFSP when a composting program that includes food scraps is already present. It is beneficial to have food scraps collected separately from other organic waste because it “...provides opportunities for hauling and processing efficiencies, especially when yard debris is seasonal” (Yepsen, 2015, p. 53). A RFSP may also be needed to further encourage residents to divert waste.

Food scraps are usually processed through composting or anaerobic digestion (Cerda, Artola, Font, Barrena, Gea, and Sanchez, 2018). Anaerobic digestion is composting without oxygen. Food scraps are broken down by microbes in airtight containers called digesters; the end product is natural gas or clean energy (Cerda et al., 2018; Vaz, 2015). Composting is a process that breaks down organic material into a soil like substance that can be used for soil nutrients and fertilizer. Using compost for farming or gardening helps keep soil in place and reduces the amount of water needed (Anderson \& Liss, 2010). It also diverts organic waste from landfills, mitigates groundwater contamination, reduces the amount of greenhouse gasses (GHG) released into the atmosphere, and can be turned into useful products ( $\mathrm{Li}, \mathrm{Lu}, \mathrm{Ren}, \& \mathrm{He}$, 2013). General composting involves any material that is biodegradable (food, leaves, and other vegetation); food scrapping can be considered as a type of composting that consists only of food scraps. In addition to other composting products, food scraps can be turned into animal feed, oils and fats, 
and recovered water (Gunders \& Bloom, 2017; Sustainable Alternative Feed Enterprises [SAFE], 2016).

Zero waste, sometimes called sustainable waste (Silva, Rosano, Stocker, and Gorissen, 2017), has varied meanings. The overall concept of zero waste is that $100 \%$ of waste is diverted, or at least only a minimal amount is sent to the landfills. Another key concept of zero waste is the circular economy. In a linear economy, products are created, sold, and then disposed of. In a circular economy, products are created, sold, and then the materials are re-used (Silva et al., 2017). In zero waste, waste is not just dealt with by waste management systems, but also by industries responsible for the design and production of products (EPA, 2017a; Silva et al., 2017).

Despite the increased number of curbside recycling, composting, and food scrap programs, the rate of diverted waste recently decreased after decades of growth. In 2013 the EPA determined that $34.4 \%$ of the 254.1 million tons of generated Municipal Solid Waste (MSW) was diverted through recycling and composting, but in 2011 Americans diverted 34.7\% (Desilver, 2016). A report by CalRecycle supports the EPA's findings; they found that the statewide recycling rate decreased from 65\% in 2013 to 63\% in 2015. CalRecycle attributed the decrease in diverted waste to increasing populations and an improved economy (Romanow, 2017).

\section{SB 1383 \& Related Policies}

California was introduced to mandatory organics recycling prior to SB 1383. Assembly Bill (AB) 1826 was signed by the governor in 2014; it required local governments to divert organic waste from businesses and multifamily residential buildings (MFB) that consisted of five or more units. "Organic waste” in AB 1826 refers to food scraps, green waste, food soiled paper, and non-hazardous wood waste. AB 1826 is applicable to commercial entities that generate a 
certain amount of waste. However, this amount threshold will decrease over time and an increasing number of businesses will be required to divert organics (CalRecycle, 2018c).

The Governor of California signed Senate Bill (SB) 1383 in 2016 (CLI, 2016). The intent of the bill was to reduce short-lived climate pollutants (SLCP), which are pollutants that stay in the atmosphere for a shorter period of time but are more potent than carbon dioxide; methane is one of the SLCPs that the bill targets (CARB, 2018). Major components of the bill included reducing methane emissions from livestock and dairy manure operations, reducing organic waste in landfills, and recovering edible food. Another intent of the bill was to further steer the state towards reaching the goals of the Global Warming Solutions Act of 2006 which set GHG emission level goals (CLI, 2016). It was intended that local governments be responsible for organic waste diversion through SB 1383 and the WMA. The WMA required local governments to submit waste management plans to the DRRR (CLI, 2016); now local governments will be required to add an organic waste diversion component to their plans.

With the history and the severity of global warming, concerns over GHG emissions, and shrinking landfill space, one wonders why every municipality does not have a recycling system, let alone a composting or RFSP. Since the Congress was able to pass laws such as the Clean Air Act of 1963 (to control air pollution), and the Solid Waste Disposal Act of 1965 (to regulate waste disposal), it is clear that they are legally able to pass legislation that would require more waste diversion efforts. The closest that federal legislation came to recycling was the Resource Conservation and Recovery Act (RCRA) of 1976, which created guidelines and further regulated solid waste disposal, but demanded little recycling effort. RCRA required the federal government to increase its purchase of products made with recycled materials, and to publish manuals on curbside recycling programs (E/The Environmental Magazine, 2010). Further federal recycling 
and composting laws may be absent due to political barriers. Federal lawmakers are reluctant to take waste management regulatory power from the states because states have different needs. For example, states with extra land for landfill use are not as concerned with encouraging high recycling rates as compared to states that have limited landfill space. There have been a few attempts to create a national minimum recycling law, but proposals never made it out of committee hearings (E/The Environmental Magazine, 2010).

The House of Representatives was considering legislation (informally called the Farm Bill) to reduce food waste, although the intent seemed to be to create resources rather than to mitigate environmental issues (Turmelle, 2018). Earth Talk (2018) also discussed why there is no national recycling law. They stated that recycling is a hard sell because the economy is run by a free market, and in many places landfilling is inexpensive and efficient (Earth Talk, 2018). Studies showed that the value of the items recycled was not enough to cover the costs of the collection and processing fees for most municipalities. They also stated that the landfill crisis of the 1990s was exaggerated and that most landfills have capacity for more waste and do not pose threats to surrounding communities (Earth Talk, 2018). 


\section{LITERATURE REVIEW}

\section{Food Waste}

Food ends up at landfills and incinerators more than any other material (EPA, 2019a). Food waste makes up about 21.6\% of MSW (EPA, 2019a), about 52 million tons of food is sent to landfills each year (Rethink Food Waste Through Economics and Data, 2019). Gunders and Bloom (2017) did an extensive report on how food goes from farm to landfill and what methods can be implemented to reduce food waste. They found that wasted decomposing foods make up $2.6 \%$ of GHGs such as methane, and that emissions from food waste were equivalent to 37 million passenger vehicles (Gunders \& Bloom, 2017). There were no significant socioeconomic factors correlated with food waste; Americans in general dispose of $40 \%$ of their food (Gunders \& Bloom, 2017). A Food Recovery Hierarchy (FRH) created by the EPA is available to demonstrate how to divert food from landfills, see Appendix A. The hierarchy suggested that food scraps be used for animal feed first, then for industrial purposes (for example, industries can use food scrap oils for fuel), then for enriching the soil, and then as a last resort be sent to the landfill or incinerator (Gunders \& Bloom, 2017).

\section{Food Scrap Programs and Composting}

Cerda, Artola, Font, Barrena, Gea, and Sanchez (2018) analyzed the technical challenges of processing food waste. The most common methods to process food waste were through composting and anaerobic digestion (Cerda et al., 2018). Composting yields soil amendment, and anaerobic digestion yields biogas which consists mainly of methane (Cerda et al., 2018). Cerda et al. (2018) stated that neither process is detrimental to the environment, despite the fact that methane is the largest product created during anaerobic digestion. They also stated that both processes reduce landfill emissions of GHGs (Cerda et al., 2018). 
Pollans, Krones, and Ben-Joseph (2017) studied RFSPs in mid-size U.S. cities (populations between 100,000 and one million people). They found a weak association between socioeconomic factors and RFSPs. Their main findings were that RFSPs may be more successful if (1) they are developed on a pre-existing infrastructure, (2) use a pay as you throw (PAYT) system (where consumers are charged based on the size of their garbage bins or amount of trash), (3) already have policies that prioritize food waste, and (4) already have a similar program (less complex than the curbside method) (Pollans et al., 2017). Pollans et al. (2017) concluded that a more complex RFSP needs to be developed over time.

Johnston (2017) reported on the multiple food scrap methods used in the City of Alexandria, Virginia. Methods included Farmers Market Drop Off, curbside, a yearlong apartment building pilot program, and a school program (Johnston, 2017). The curbside method only had a participation rate of $17 \%$. The pilot program for apartment buildings had a lower participation rate of 12-13\% (Johnston, 2017). The city decided to invest in a broader drop off program. The reason the curbside method was abandoned was that a consultant did not think it would make much of an environmental impact due to the low participation rate (Johnston, 2017), and compostable curbside programs are not affordable with low participation rates (Layzer and Schulman, 2014).

Several comprehensive studies on food scrapping in the United States were found. The Center for a Competitive Waste Industry conducted a study on 121 RFSPs in the U.S. and Canada (Anderson \& Liss, 2010). One third of the programs collected food scraps separately, and about half collected food with yard trimmings (Anderson \& Liss, 2010). Findings demonstrated that more than two-thirds of organic waste can be diverted (Anderson \& Liss, 2010). The largest number of programs reported that organics were collected separately 
(meaning organics are in a separate container) once a week (Anderson \& Liss, 2010). Anderson and Liss (2010) stated that changes in policy, operations, and public attitude needed to occur in order to expand RFSPs throughout the U.S.

Anderson \& Liss (2010) suggested the following policy changes. First, raise landfill fees; this would encourage municipalities to keep their landfill destined waste amounts low (Anderson \& Liss, 2010). Second, have landfill owners consider the future costs of landfills (Anderson \& Liss, 2010). It is assumed that the authors meant to have landfill owners consider future landfill costs when determining fees. Third, eliminate recycling credit for alternative daily covers (ADC). In California ADCs made up of yard trimmings (Anderson \& Liss, 2010) cover landfills at the end of the day to prevent vector control problems, odor, and other issues (CalRecycle, 2019a). Through ADCs, compost and green materials can be counted as diversion even though both still technically end up in landfills (CalRecycle, 2019a), Anderson \& Liss (2010) suggested not allowing this. The fourth suggested policy change was to streamline permit processes for organic composting; and lastly, to give compost carbon trading value (Anderson \& Liss, 2010).

One suggested operation systems change was reducing the number of times non-diverted waste is collected (Anderson \& Liss, 2010). For example, Toronto, Canada only collects nondiverted waste once every other week (Anderson \& Liss, 2010). Anderson and Liss (2010) stated that reducing the collection of non-diverted waste this way would be less expensive for the waste management system than landfilling. Other operation system changes included enclosed composting and incorporating anaerobic digestion (Anderson \& Liss, 2010).

Public attitudes need to be relatively positive or accepting for a RFSP to work. Anderson and Liss (2010) suggested two ways to change public attitude on RFSPs. First, emphasize that through RFSPs, resources are being conserved: For example, compost from RFSPs keeps soil 
together and reduces water needs (Anderson \& Liss, 2010). Second, Anderson and Liss (2010) recommended avoiding the term "waste," whenever possible. For example, instead of saying food waste, say food scraps. The authors believed that this change in semantics would get the public to see scraps as a resource rather than garbage or waste (Anderson \& Liss, 2010; Freeman \& Skumatz, 2011b; Nelson, Jarland, \& Katsaros, 2015).

The EPA funded a study on food scrap composting programs in the U.S. (Freeman \& Skumatz, 2011a). At the time of the study, 183 programs were identified (6 more were identified after the report was published), with more than $80 \%$ of the programs in just 3 states: California, Minnesota, and Washington (Freeman \& Skumatz, 2011a). Roughly 2.7\% of the U.S. population lived in a community with a food scrap program. Freeman and Skumatz (2011a) stated that cities with food composting programs had significant diversion rates, more than 50\%. The authors expressed that many of these cities had successful recycling and/or yard trimming diversion programs prior to adding food scraping (Freeman \& Skumatz, 2011a).

The average participation rate ranged from $35-45 \%$, with the highest at $95 \%$ and lowest at 10\% (Freeman \& Skumatz, 2011a). The city with the $10 \%$ participation rate imposed a separate food scrapping fee (Freeman \& Skumatz, 2011a). About one third of the programs included food scrapping in their overall trash fees (Freeman \& Skumatz, 2011a). Ten percent of the programs were mandatory; residents were penalized for not sorting out food scraps from their trash (Freeman \& Skumatz, 2011a). Freeman and Skumatz (2011a) determined that the most common and successful (and easy to implement) food scrap program model was where landfill tipping fees for mixed waste were higher than fees for disposing of organics; people were motivated to divert more waste to keep their mixed waste amounts to a minimum. Organics were on average 29\% cheaper to dispose of than trash (Freeman \& Skumatz, 2011a). However, 
Freeman and Skumatz (2011a) stated that there were some successful programs that did not have more expensive tipping fees.

Freeman and Skumatz (2011b) analyzed the EPA’s 2011 comprehensive study on food scrapping in the U.S. to determine best practices; their intent was to accelerate food scrap program implementation. The authors found that the most common barriers to start or have a successful food scrap program were a lack of political support, permitting and infrastructure issues, costs, contamination, and public perceptions (Freeman \& Skumatz, 2011b). See Table 1 for a summary of solutions. To get political backing, Freeman and Skumatz (2011b) suggested educating elected officials, business leaders, and other influential stakeholders on how food scrapping lowers waste system costs, saves landfill space, assists in meeting GHG goals, is good for the environment, and can create jobs.

Odor management was an environmental and social concern (Freeman \& Skumatz, 2011b); if not managed it can shut down plants (Cerda et al., 2018). Clearly defining terms is meant to clear permitting issues. For example, if food waste is defined as MSW then a facility must obtain a solid waste facility permit to accept food scraps (Freeman \& Skumatz, 2011b). The public was resistant to food scrapping due to the perception that it was a disgusting chore and attracted pests (Freeman \& Skumatz, 2011b). Freeman and Skumatz (2011b) suggest persistently educating the public on food scrapping collection methods, such as storing them in the freezer or layering them with yard trimmings and so on. The public should also know that pests tended to be an issue at the facilities rather than at residences (Freeman \& Skumatz, 2011b). 
Table 1

\begin{tabular}{|l|l|l|l|l|l|l|}
\hline & $\begin{array}{l}\text { Political } \\
\text { Support }\end{array}$ & Infrastructure & Permitting & Costs & Contamination & $\begin{array}{l}\text { Public } \\
\text { Perceptions }\end{array}$ \\
\hline Solutions & Education & $\begin{array}{l}\text { Spread out } \\
\text { facilities }\end{array}$ & $\begin{array}{l}\text { Clearly define } \\
\text { food scraps, yard } \\
\text { trimmings, and so } \\
\text { on }\end{array}$ & $\begin{array}{l}\text { Partner with } \\
\text { neighboring counties } \\
\text { and communities for } \\
\text { outreach }\end{array}$ & $\begin{array}{l}\text { Education on } \\
\text { appropriate } \\
\text { sorting }\end{array}$ & $\begin{array}{l}\text { Education and } \\
\text { persistence }\end{array}$ \\
\hline & $\begin{array}{l}\text { Odor } \\
\text { management }\end{array}$ & Lower permit fees & $\begin{array}{l}\text { Only give kitchen } \\
\text { pails when requested }\end{array}$ & & $\begin{array}{l}\text { Education on } \\
\text { food } \\
\text { collecting } \\
\text { techniques }\end{array}$ \\
\hline & $\begin{array}{l}\text { Learn to point } \\
\text { out difficult } \\
\text { loads }\end{array}$ & $\begin{array}{l}\text { Allow facilities } \\
\text { that accept yard } \\
\text { trimmings to } \\
\text { accept food scraps }\end{array}$ & Use PAYT & $\begin{array}{l}\text { Education on } \\
\text { pests }\end{array}$ \\
\hline & $\begin{array}{l}\text { Have a pilot } \\
\text { program to } \\
\text { perfect the } \\
\text { processing } \\
\text { method }\end{array}$ & & $\begin{array}{l}\text { Incorporate food } \\
\text { scrapping fee into } \\
\text { overall trash fee }\end{array}$ & & \\
\hline & & & $\begin{array}{l}\text { Alternating diverted } \\
\text { waste pickups days }\end{array}$ & & & \\
\hline
\end{tabular}

Layzer and Schulman (2014) authored the most recent comprehensive report found.

They analyzed curbside composting programs and challenges in 16 municipalities; six were large cities, three were mid-size cities, four were small towns, three were counties, and one city was Canadian. This selection was chosen to analyze a wide range of experiences to determine distinct benefits and challenges (Layzer and Schulman, 2014). The authors found that effective curbside compostables programs tend to be developed easily in places where there are waste diversion mandates at the state or county level, high or rising landfill costs, a pre-existing infrastructure for curbside yard waste programs, and a nearby processing facility (Layzer \& Schulman, 2014).

Most of the data on cases studied included total organic waste in pounds per capita for a single year (Layzer \& Schulman, 2014). However, some case studies’ per capita numbers were from programs that served only residential single-family households, while some programs also included some high rises and/or businesses (Layzer \& Schulman, 2014). Few municipalities measured the percentage of food in the diverted organic waste; however, the authors concluded that about $57 \%$ of organic waste was composed of food scraps in the localities they studied 
(Layzer \& Schulman, 2014). In summary, results could not be exactly compared because the case studies did not have a universal result reporting method and programs differed (Layzer and Schulman, 2014). See Table 2 for a summary of Layzer and Schulman's (2014) data on the programs analyzed. 
Table 2

\begin{tabular}{|c|c|c|c|c|c|c|c|c|}
\hline & $\begin{array}{l}\text { Population } \\
\text { (in millions) }\end{array}$ & Program & $\begin{array}{l}\text { Start } \\
\text { Date }\end{array}$ & $\begin{array}{l}\text { Organics } \\
\text { Diverted }\end{array}$ & $\begin{array}{l}\text { Single } \\
\text { Home }\end{array}$ & $\begin{array}{l}\text { Multi } \\
\text { Home }\end{array}$ & Commercial & Voluntary \\
\hline \multicolumn{9}{|l|}{ Municipality } \\
\hline Alameda County, CA & 1.51 & & 2002 & $\begin{array}{l}270 \text { pounds } \\
\text { per capita }\end{array}$ & & $x$ & $x$ & $X$ \\
\hline Arvin, CA & 0.02 & & 2006 & $\begin{array}{l}225 \text { pounds } \\
\text { per capita }\end{array}$ & & & & \\
\hline Berkeley, CA & 0.11 & & 2007 & $\begin{array}{l}395 \text { pounds } \\
\text { per capita }\end{array}$ & $\mathrm{X}$ & $?$ & $x$ & \\
\hline Boulder, Colorado & 0.01 & & 2005 & $\begin{array}{l}370 \mathrm{lbs} \text {. per } \\
\text { household }\end{array}$ & $\mathrm{X}$ & & & $\mathrm{X}$ \\
\hline Burnsville, Minnesota & 0.06 & & $\begin{array}{l}2002, \\
\text { now } \\
\text { cancelled }\end{array}$ & & & & & \\
\hline $\begin{array}{l}\text { Cambridge, } \\
\text { Massachusetts }\end{array}$ & 0.11 & & 2014 & & & & & \\
\hline Denver, Colorado & 0.62 & & 2010 & $\begin{array}{l}870 \mathrm{lbs} \text {. per } \\
\text { household }\end{array}$ & & & & $\mathrm{x}$ \\
\hline $\begin{array}{l}\text { Hennepin County, } \\
\text { Minnesota }\end{array}$ & 1.17 & & 2013 & $\begin{array}{l}180 \text { pounds } \\
\text { per capita }\end{array}$ & & & & \\
\hline $\begin{array}{l}\text { King County, } \\
\text { Washington }\end{array}$ & 1.93 & & 2002 & $\begin{array}{l}230 \text { pounds } \\
\text { per capita }\end{array}$ & $\mathrm{X}$ & & & $X$ \\
\hline New York City & 8.35 & & 2013 & & $\mathrm{X}$ & $x$ & & $x$ \\
\hline Portland, Oregon & 0.59 & $\begin{array}{l}\text { Include } \\
\text { the Food }\end{array}$ & 2011 & $\begin{array}{l}288 \\
\text { (residences), } \\
361 \text { (with } \\
\text { commercial) } \\
\text { pounds per } \\
\text { capita }\end{array}$ & $\mathrm{X}$ & & $\mathrm{x}$ & \\
\hline San Francisco, CA & 0.81 & & 2000 & $\begin{array}{l}541 \text { pounds } \\
\text { per capita }\end{array}$ & $\mathrm{X}$ & $\mathrm{x}$ & $\mathrm{x}$ & \\
\hline Seattle, Washington & 0.62 & & & $\begin{array}{l}390 \text { pounds } \\
\text { per capita }\end{array}$ & $\mathrm{X}$ & $x$ & $x$ & \\
\hline Toronto, Canada & 2.80 & $\begin{array}{l}\text { Green Bin } \\
\text { Program }\end{array}$ & 2005 & $\begin{array}{l}91 \text { pounds } \\
\text { per capita }\end{array}$ & $\mathrm{X}$ & & $x$ & \\
\hline $\begin{array}{l}\text { Wenham \& Hamilton, } \\
\text { Massachusetts }\end{array}$ & 0.01 & & 2012 & & & & & \\
\hline
\end{tabular}


Toronto, Canada is the fifth largest city in North America. The authors stated that Toronto was notable for two reasons. First, they accepted plastic bags and the disposal of diapers and animal waste. The second reason is that they invested in their own processing plant rather than using the facilities of a private business (Layzer and Schulman, 2014). The city created their own plant when their previous nearby plant shut down, and costs to transport waste to the next available plant were too high (Layzer and Schulman, 2014).

San Francisco, California was the first American city to adopt a program with curbside composting and food scrapping (Layzer \& Schulman, 2014). The authors stated that San Francisco's approach to composting was the most sophisticated according to many measures and was the most comprehensive (Layzer \& Schulman, 2014). All properties, residential and nonresidential, are required to separate waste into separate disposal bins (Layzer \& Schulman, 2014). San Francisco collected the most compostables in the country (EPA, 2019b; Layzer \& Schulman, 2014). Seattle, Washington had a curbside compostable program that rivaled San Francisco's program in comprehensiveness; however, it was limited to single family homes and a number of businesses (Layzer and Schulman, 2014).

Portland, Oregon faced many difficulties trying to start a curbside program due to state restrictions on organic waste processing plants (Layzer \& Schulman, 2014). Those restrictions were altered in 2011, and Portland then unveiled their composting program (Layzer and Schulman, 2014). Denver, Colorado nearly closed their program in 2010 following a costly pilot program of 3,000 households (Layzer and Schulman, 2014). Their intent to cancel the program was met with strong opposition from composting supporters. The city then offered the service at \$107 per year. In 2013, 2,300 households were subscribed to Denver’s program (Layzer and Schulman, 2014). 
New York City implemented a pilot program in 2013; 3,500 households and two apartment buildings were included (Layzer \& Schulman, 2014). Later that year the program was expanded to 30,000 households and a few high-rises. The city intended to expand the program to 100,000 households by 2014. Their goal was to make curbside composting a mandated city wide effort (Layzer and Schulman, 2014). Berkeley, California was considered to have the most effective composting program in the country. The city's population was considerably environmentally conscious and progressive. Although Berkeley has encouraged backyard composting since the 1970s, food did not become part of the compost program until 2007 (Layzer \& Schulman, 2014). The city directly managed hauling but worked with nonprofits and the private sector to enhance participation (Layzer and Schulman, 2014).

Boulder, Colorado also has a population known for its progressive views that is supportive of composting. However, the region's low tipping fees gave haulers incentive not to encourage waste diversion. The city then required the haulers to provide composting and recycling to their customers and to institute a PAYT system (Layzer and Schulman, 2014).

Cambridge, Massachusetts did not have a curbside program at the time of Layzer and Schulman's (2014) study despite political and public interests. The problem was that the city did not have access to a large enough organic waste processing facility and did not know the plant capacity they needed. After receiving a grant and conducting a study on residential food scrap collection the city had plans to begin a curbside compost program in 2014 (Layzer and Schulman, 2014).

As of 2014, the program in Burnsville, Minnesota was terminated due to a significantly low participation rate, at the end only 30 households were participating. This result was surprising, as the population was considered to be environmentally conscious. Factors that led to 
the termination included issues with affordability of the collection system with such low participation, the cooperation of the haulers, and maintaining public interest. Burnsville plans to reinstate the program once a facility is located closer to the city (Layzer and Schulman, 2014).

Arvin, California started a curbside compostables program after being fined by the state for failing to meet a waste diversion benchmark. The authors concluded that Arvin diverted a very good amount of waste considering the small size of the city and population (Layzer and Schulman, 2014).

What is unique about Wenham, Massachusetts and Hamilton, Massachusetts is that the programs in these towns were created by passionate and committed citizens. There was a volunteer recycling committee that supported outreach and education to ensure an acceptable level of participation. In one year, the town of Wenham collected 103 tons of organics and saved $\$ 15,000$ in waste costs. In nine months, the town of Hamilton collected 229 tons of organic waste and saved more than \$25,000 (Layzer and Schulman, 2014).

Alameda County in California was one of the first counties in the US to incorporate curbside compostable programs. Currently all 14 municipalities of their county have curbside compostable collection services. The county diverted at least 180,000 tons of residential organic waste in 2012; 5-10\% was composed of food waste (Layzer and Schulman, 2014).

In King County, Washington, the compostables curbside program was initially only offered to four towns and cities to test different approaches. As of 2014 all of the county’s municipalities, except Seattle and most of the unincorporated territories, offer the same compostable program. The program was not mandated, but two-thirds of single households in the county used these services. In 2011, households diverted 150,000 tons of organic waste; 7\% consisted of food scraps and soiled paper (Layzer and Schulman, 2014). 
Hennepin County, Minnesota consists of 45 cities and towns. They had difficulty launching a curbside compostables program due to a limited processing capacity and open hauling. As of 2013 only 12 cities offered these programs. The total number of households in Hennepin County using this program was 17,000 in 2013. The program generated 50,000 tons of diverted organic waste (Layzer and Schulman, 2014).

Layzer and Schulman (2014) summarized the unique processes and difficulties for counties and large, medium, and small cities. Counties begin curbside composting by launching programs in a few cities to create models to better implement the programs for the rest of the municipalities. The models also initiate creating or expanding the infrastructure needed for these programs. Counties may help establish programs in other cities and towns by offering grants, setting reduction goals, and lobbying to change state policies on organic waste diversion. The challenges for large cities (San Francisco, Toronto, Denver, Seattle, Portland, and New York City) are finding processing facilities large enough to handle city capacities and expanding the programs to high rise and multifamily residences. MFBs are a challenge because (1) buildings have difficulty making space for the additional organics bin, (2) monitoring and fining individual residents for contamination is almost impossible, and (3) it is not convenient for residents to travel to their dumpsters to dispose of separate waste piles (Layzer \& Schulman, 2014). In fact, because trash chutes are convenient (and most buildings only have one), buildings with trash chutes reduce the amount of diverted waste (Layzer \& Schulman, 2014).

Medium sized cities (Berkeley, Boulder, and Cambridge) face fewer challenges; but they also may have difficulty finding a processing facility to handle their capacity requirements and expanding the program to MFBs. They may also face resistance from the haulers. Smaller cities and towns (Burnsville, Arvin, Hamilton and Wenham) face the least difficulty in establishing 
curbside compostable programs. Their challenges include getting the participation of local officials, waste contamination, and getting enough participants to keep the program affordable (Layzer and Schulman, 2014).

\section{Sustainable and Zero Waste}

Silva, Rosano, Stocker, and Gorissen (2017) compared three major cases where there were transitions to sustainable waste: San Francisco’s Zero Waste Program (SFZW), Flanders’s (one of Belgium’s 3 regions) Sustainable Material Management Program (FSMM), and Japan’s Sound Material-Cycle Society Program (JSMCS). SFZW was selected for this study due to being one of the more recognized and publicized zero waste policies (Silva et al., 2017). FSMM was selected for being the first regional attempt towards zero waste policies (Silva et al., 2017). The selection for Japan's program was not discussed, although it may have been to study sustainable waste policies on a national level.

Silva et al. (2017) attributed the success of SFZW to multiple factors. First, a pre-existing recycling culture welcomed civic engagement, educational programs, and openness to make behavioral changes (Silva et al., 2017). Second, there was a pre-existing waste and recycling infrastructure, and a system and processes already in place (Silva et al., 2017). Third, the management and delivery of the program was through a centralized system. The SF Environment Department manages the program, and it is implemented by a single company for the entire city, Recology (Silva et al., 2017). Fourth, San Francisco invested a significant amount of money into the policies (Silva et al., 2017). Fifth, the policies left little opportunity for non-compliance (Silva et al., 2017).

Although San Francisco reached an 80\% diversion rate, the authors were concerned that focusing on the percentage of waste diverted did not actually reduce waste (Silva et al., 2017). 
The diversion rate was calculated by a method used across California. However, having an $80 \%$ diversion rate does not measure the amount of waste; using percentages may hide the fact that residents are actually producing more solid waste (Silva et al., 2017). The authors were also critical of San Francisco's soft policies on the producing and manufacturing side of consumerism, while having regulations on the consumption side. All stages of goods' life cycles must be targeted to reduce the most waste possible (Silva et al., 2017).

The authors stated that San Francisco must tackle a few issues before it can reach its 100\% diverted waste goal (Silva et al., 2017). First, they must determine how to treat noncompostable or non-recyclable materials (Silva et al., 2017). Second, they must incorporate a three-chute system- recycle, compost, landfill - for residents to sort waste in higher density living and inner city apartments. Most of these residences have single chute systems due to previous building codes; San Francisco has already passed legislation to ensure that new apartment buildings have the three-chute system (Silva et al., 2017).

Flanders, Belgium has a waste program that is conducted in a manner almost opposite of SFZW. While SFZW is more focused on the end of a product's lifecycle, FSMM is based on a circular economy model, where materials are kept in use for as long as possible, unlike in a linear economy of make, use, and dispose. Another key difference between SFZW and FSMM is that in SFZW the program was overseen in a centralized manner, leaving out other industries and key players; FSMM works by including several industries and non-government organizations. Under their program, more companies are using sustainable materials and are aiming to develop products more compatible with a circular economy (Silva et al., 2017).

Japan’s waste system consisted of recycling, recovery, and disposal (Silva et al., 2017). Under JSMCS, which originated in 2000, reduction and reuse is prioritized ahead of recycling; 
this reprioritization was intended to reduce mass-consumption and the generation of waste (Silva et al., 2017). Like SFZW, JSMCS uses a centralized government for program management (Silva et al., 2017). A key difference between JSMCS and other programs is their emphasis on indicators. They use effort indicators which measure emissions, number of recycling plans developed by local government, and average use years of goods (Silva et al., 2017). They also have indicators measuring the reduction in resources inputs, the reuse of materials, and the tonnage of final disposal amounts (Silva et al., 2017).

Cohen (2018) reported on New York City’s progress towards becoming a sustainable city. This report was included in the literature review to explore different options of food waste processing and to explore why and how methane is produced and used, despite the concerns of methane pollution. The city started composting efforts as early as 1993 (Cohen, 2018). The current mayor's office recognized that addressing organic waste was critical to meeting zero waste goals; a third of their waste is composed of food scraps (Cohen, 2018). The city came up with several ways to divert waste. Schools use compostable plates and utensils (Cohen, 2018). They have plans to convert a portion of their food waste to biogas and fertilizer (Cohen, 2018). And another portion of their food waste is mixed with sludge to make methane gas. Forty percent of the produced methane is used to run the plant and the rest is burned (Cohen, 2018).

Although Cohen's (2018) report sounded promising, other sources say the city's residents were resisting the program and that expansion of the program was being halted (Associated Press, 2018). People are resistant to RFSPs because they believe it will attract pests and collecting and keeping rotting food will be unpleasant (Associated Press, 2018; MacBride, 2015). It was recommended that residents be informed that separated food is no more likely to 
attract pests than food scraps in black bins; they may use bins and liners if concerned with odors and pests (MacBride, 2015). 


\section{METHODOLOGY}

The research methodologies used included components of Sylvia and Sylvia's (2012) Process Evaluation and Bardach and Patashnik’s (2016) Smart (Best) Practices method. The process evaluation is typically used for programs and consists of four stages: Problem identification, solution development, implementation, and feedback evaluation. Because most of the food scrapping programs and practices were new (developed and implemented within the last 2 years) and no new solution or alteration was implemented and tracked for this report, this research project focused on stages I and II. SB 1383 and cities’ compliance attempts were evaluated instead of a specific program. The problem SB 1383 was meant to mitigate, as previously mentioned, was methane production at landfills; information on the issue was taken from CARB and CalRecycle.

A list of smart practices was developed from reviewing online literature and case studies of RFSPs and/or programs with a food scrapping component. This report was meant to demonstrate which smart practices each of the 10 cities were using, as well as which best practices a city may pursue to have a more effective program. The analysis also includes explanations on why or why not a missing smart practice may work for a specific municipality.

The solution development portion of the evaluation provided information on selected cities and their programs that consisted of practices that made the city compliant with SB 1383 (at this early stage, compliance simply meant that cities had an active program that aimed to divert organic waste from landfills). Selected cities included Cupertino, Livermore, Milpitas, Morgan Hill, Mountain View, Palo Alto, San Francisco, San Jose, Santa Clara, and Sunnyvale. These cities were selected for having active organic waste diversion efforts and to represent different city sizes and food scrapping approaches. Program details, intent, and other information 
were taken from city websites and contacting cities’ environmental departments. Populations, percentages of the populations with a Bachelor's degree or more, and median incomes were taken from the United States Census Bureau; the latest provided information were estimations for 2017. Demographics were not analyzed, they were only provided for other municipalities to see what methods similar cities used. 


\section{FINDINGS}

\section{Problem Identification}

Organic waste is discarded material that is biodegradable and is made up of plants or animal material such as food scraps, biodegradable products, and yard waste. As organic waste decomposes in landfills, methane is released into the atmosphere (CARB, 2018). Methane is a particularly harmful GHG because it is a short-lived climate pollutant (SLCP), a pollutant that stays in the atmosphere for a shorter period of time but is much more potent (CARB, 2018). Although organic material accounts for a significant portion of landfill waste (food scraps alone make up 17-18\%), it can be regularly diverted (CalRecycle, 2019b). SB 1383 was passed to reduce the amount of organic waste in landfills to alleviate methane emissions (CalRecycle, 2019b). Specifically, SB 1383 mandates that by 2020, state organic waste levels in landfills are to be reduced to $50 \%$ of the levels from 2014. By 2025, these organic waste levels should be reduced by 75\% (CalRecycle, 2019b).

More specific rules and regulations were expected to be finalized by late 2018 or early 2019; they will be in effect by 2022 (CalRecycle, 2019b). However, organic waste diversion plans were expected to be adopted by 2018 or 2019 to provide governments time to implement and organize program/solution funding, infrastructure, and so on (CalRecycle, 2019b). As

previously mentioned, statewide organic waste levels must be reduced by $50 \%$ and CalRecycle must analyze the progress of SB 1383 goals by 2020 (CalRecycle, 2019b). To meet these mandates, and because programs were expected to be adopted by 2019, the state and local governments must plan and implement strategies to divert organic waste as soon as possible. 


\section{Smart Practices}

The bulk of smart practices were taken from Anderson and Liss (2010), Freeman and Skumatz (2011a, 2011b), and Layzer and Schulman (2014) since they studied in depth the techniques, methods, challenges, and various components of 15-183 curbside compostable programs. Their reports were designed to demonstrate how to develop and implement such programs. Best practices were also taken from SFZW program, because they are nationally recognized as implementing one of the most successful diversion programs, with one of the highest diversion rates in the country (EPA, 2019b). San Francisco had a list of best practices available for municipalities to copy. Table 3 summarizes the smart practices found, sorted by the amount of support received. 
Table 3

\begin{tabular}{|c|c|}
\hline Smart Practices & Sources \\
\hline Financial Incentive: High landfill tipping costs & $\begin{array}{l}\text { Anderson \& Liss (2010); Freeman \& Skumatz (2011a); Gieslar } \\
\text { (2017); Layzer \& Schulman (2014); and SF Environment (2019c) }\end{array}$ \\
\hline Public outreach and education & $\begin{array}{l}\text { Anderson \& Liss (2010); Freeman \& Skumatz (2011b); Lazyer \& } \\
\text { Schulman (2014); and SF Environment (2019c) }\end{array}$ \\
\hline Policies that enforce organic diversion & $\begin{array}{l}\text { Layzer \& Schulman (2014); Pollans et al. (2017); SF Environment } \\
\text { (2019c); and Silva et al. (2017) }\end{array}$ \\
\hline Financial Incentive: Use a PAYT or similar system & $\begin{array}{l}\text { Freeman \& Skumatz (2011b); Layzer \& Schulman (2014); and } \\
\text { Pollans et al. (2017) }\end{array}$ \\
\hline Pre-existing infrastructure and/or yard waste program & $\begin{array}{l}\text { Freeman \& Skumatz (2011a); Layzer \& Schulman (2014); Pollans } \\
\text { et al. (2017); and Silva et al. (2017) }\end{array}$ \\
\hline Starting with a pilot program & $\begin{array}{l}\text { Freeman \& Skumatz (2011b); Layzer \& Schulman (2014); and } \\
\text { Pollans et al. (2017) }\end{array}$ \\
\hline Pursuing political support & $\begin{array}{l}\text { Freeman \& Skumatz (2011b); Layzer \& Schulman (2014); and } \\
\text { Silva et al. (2017) }\end{array}$ \\
\hline Not using the term, "waste” & $\begin{array}{l}\text { Anderson \& Liss (2010); Freeman \& Skumatz (2011b).and Nelson } \\
\text { et al.,(2015) }\end{array}$ \\
\hline Using only 1 or a few haulers & Layzer \& Schulman (2014); and Silva et al. (2017) \\
\hline Partnering with nonprofits and the community & Freeman \& Skumatz (2011b); and Layzer \& Schulman (2014) \\
\hline Pursuing grants & Freeman \& Skumatz (2011b); and Layzer \& Schulman (2014) \\
\hline Making permits for food processing easier to obtain & Anderson \& Liss (2010); and Freeman \& Skumatz (2011b) \\
\hline Reducing pickups & Anderson \& Liss (2010); and Freeman \& Skumatz (2011b) \\
\hline Using enclosed processing, anaerobic digestion & Anderson \& Liss (2010) \\
\hline Using a nearby processing facility & Layer \& Schulman (2014) \\
\hline Forbidding ADCs & Anderson \& Liss (2010) \\
\hline Considering future costs of landfills & Anderson \& Liss (2010) \\
\hline
\end{tabular}

High Landfill Tipping Fees. SF Environment (2019c) had a very short list of best practices which included economic incentives. Geislar (2017) found that economic incentives were among “The strongest predictors of recycling behaviors” (pg. 572). Freeman and Skumatz (2011a) stated that economic incentives, such as higher tipping fees for non-organic waste, was one of the most common and easy components to have in a food scrap composting program. In seven case studies in Layzer and Schulman's (2014) article, costs for disposing one ton of mixed waste were significantly more expensive than disposing of one ton of organic waste. To save costs on non-organic tipping fees, those cities then targeted residential organics. In some cases the difference in price was due to a free market, and in others municipalities established a 
significant cost difference and subsidized the organic waste disposal (Layzer \& Schulman, 2014). Increasing landfill tipping fees must be considered carefully since it may increase operation fees for haulers.

Public Outreach \& Education. Public education and outreach should educate people on how to sort waste (Freeman \& Skumatz, 2011b; Layzer \& Schulman, 2014; SF Environment, 2019c), and provide a way for communities to ask questions and raise concerns (Layzer \& Schulman, 2014). Public outreach and education should be extensive (SF Environment, 2019c); Layzer and Schulman (2014) recommended distributing clear, exhaustive, and consistent educational material. Education/training should be ongoing (Freeman \& Skumatz, 2011b) or else food waste streams eventually start getting contaminated (Layzer \& Schulman, 2014). Examples of public outreach and education methods include (1) posting instructional videos on cities' webpages, (2) promotional videos, (3) training residents to educate their communities, (4) assigning residents in apartment buildings to educate their neighbors and monitor waste bins, (5) branding (name the program), and (6) door-to-door outreach (Layzer \& Schulman, 2014). Anderson \& Liss (2010) said that the public needs to be aware of the importance of RFSPs in order for the program to work; they recommended emphasizing that resources are being conserved so that residents may feel that they are discarding resources rather than garbage. This can be incorporated in public outreach and education.

Policies. Layzer and Schulman’s (2014) data demonstrated that having “... an ambitious waste diversion mandate...” made conditions favorable for curbside composting programs (p. 2). One of the reasons for the SFZW's success was having policies that promoted the city's zero waste goals and were strict on compliance (SF Environment, 2019c; Silva et al., 2017). However, if policies include trash inspections, residents may fear invasion of privacy (Vaz, 
2015). Pollans et al. (2017) found that a RFSP may be more effective if there were policies in place that prioritized food waste.

Using a PAYT System. Residents are most likely to participate in curbside composting programs when the program makes composting relatively cheap and convenient. "For municipalities with PAYT systems in place, the simplest and most effective approach is to create a price differential between organics and trash collection” (Lazyer \& Schulman, 2014, p. 25). Some cities have even made compostables collection free. In the first year that San Jose, California implemented a PAYT system, recyclables increased by $149 \%$ and yard trimmings increased by 45\% (EPA, 2019c). In addition to providing residents with financial incentive to divert organic waste, PAYT systems can provide a revenue stream to cover waste management costs (Freeman \& Skumatz, 2011b; Layzer \& Schulman, 2014; Pollans et al., 2017): Municipalities become less dependent on the general budget and fiscal climate (Layzer \& Schulman, 2014). However, there have been cases where residents began generating such little waste that revenues dropped; Berkeley, California added a monthly $\$ 2$ refuse fee to compensate (Layzer \& Schulman, 2014). Pollans et al. (2017) also found that using a PAYT system improved participation and diversion rates.

Pre-existing Infrastructure or Similar Program. Layzer and Schulman (2014) found that compostable programs were more viable when there was a pre-existing infrastructure for a yard waste program because (1) the community had already been introduced to the habit of sorting waste, (2) a yard waste program made the community more receptive to a RFSP, and (3) the infrastructure only needed minor adjustments to accept other organics.

Starting with a Pilot Program. The use of pilot programs before launching a full scale program allows municipalities to test different collection and processing methods, and provides 
insight on an appropriate pricing structure (Freeman \& Skumatz, 2011b; Layzer \& Schulman, 2014; and Pollans et al., 2017).

Political Support. Freeman and Skumatz (2011b) found that lack of political support was a common barrier to starting a food scrap program: They suggested educating political players for support. Having political support can provide the leverage a city needs to get a compostables program up and running (Layzer \& Schulman, 2014).

Avoiding the term, “Waste.” The idea behind not using the term, "Waste” is getting the public to see food scraps as a resource, not waste (Anderson \& Liss, 2010; Freeman \& Skumatz, 2011b; Nelson et al., 2015). The advantage of this smart practice is that there is no cost.

One or a Few Haulers \& Hauler Cooperation. Layzer and Schulman (2014) stated that to start curbside composting services, a city must first gain the cooperation of haulers. This is more easily done when the city directly provides waste services or when it is contracted out to a single or few haulers (a closed hauling system). With a closed hauling system, haulers are guaranteed a customer base; this makes them more willing to invest into system changes. Haulers must compete for customers in an open hauling system (where customers choose their hauler), and therefore they may be less willing to invest in changes; changes cost money while their revenue/customers are not guaranteed (Layzer \& Schulman, 2014). Layzer and Schulman (2014) discussed a few ways cities obtained hauler cooperation in an open system. For example, Minnetonka, Minnesota offered haulers \$25 for every customer that signed up for a compostable program. Also, Wayzata, Minnesota covered the cost of compost bins. Governments can provide incentives to haulers to support composting by setting tipping fees so that disposing organic waste is significantly less. In Berkeley, California, not only do haulers pay less to dispose of 
organics, they are charged an extra \$63 per ton if their landfill destined waste contains organics (Layzer \& Schulman, 2014).

Partnering with Nonprofits and the Community. Partnering with nonprofits has been beneficial; they can be used to train and educate the public on the why and how of composting (Layzer \& Schulman, 2014). The advantage of this smart practice is that partnering with the community and other municipalities can help with costs; Freeman and Skumatz (2011b) suggested the partnership for outreach purposes if costs of a RFSP were an issue.

Pursuing Grants. Municipalities should look into county or state grants; additional funding can help develop and implement programs (Freeman \& Skumatz, 2011b; Layzer \& Schulman, 2014). CalRecycle provides grant sources on one of their webpages (CalRecycle, 2018a) and is giving grants to food waste reduction and rescue programs in 2019 (application deadline was January $31^{\text {st }}$, 2019) (CalRecycle, 2018b).

Simplify Permit Processing. Freeman and Skumatz (2011b) found that one of the most common barriers to increasing capacity of organics collected was the permitting process. The authors made a list of best management practices on the matter which include (1) lowering permit fees, (2) allowing yard trimming facilities to accept some food scraps, and (3) defining what food scraps are (Freeman \& Skumatz, 2011b). Lowering permit fees (or even removing them) for food composting facilities may encourage development of more facilities and help with the cost of a RFSP (Freeman \& Skumatz, 2011b). Some states have allowed facilities that accept yard trimmings to accept a small amount of food scraps (5-10\%) to speed up the development of RFSPs (Freeman \& Skumatz, 2011b). Food scraps can be seen as MSW; therefore, a facility must obtain a MSW permit to accept food scraps. In other cases, food scraps fall under yard trimmings/compost; such facilities that process food scraps may not be properly regulated to 
protect the environment. Therefore, it is recommended that food scraps be properly defined, and not defined as yard trimmings/compost or MSW (Freeman \& Skumatz, 2011b). Anderson and Liss (2010) recommended making regulations and the permit process simpler and clearer to make the process faster to expand RFSPs.

Reducing Pickup. Freeman and Skumatz (2011b) recommended alternating every other week pick up of organics with recyclables to help with program costs. Cities can use trucks to pick up organics one week then use the same trucks to pick up recyclables the next week. Anderson and Liss (2010) recommend reducing pick up of non-diverted waste from every week to every other week to help with program costs. The advantage of this smart practice is that it may not add costs to a program, will encourage residents to divert more waste, and can be easily undone if this method does not work well. However, Portland, Oregon found that with reducing non-diverted trash pickup to every other week, items such as diapers and cat litter started showing up in recycling carts and customers complained of smells coming from their two week old garbage (Layzer \& Schulman, 2014).

Enclosed Processing/Anaerobic Digestion. Anderson and Liss (2010) recommended enclosed processing stating that it will reduce emissions, water resources, and leaks. The enclosures do not need to be complex; enclosures can consist of plastic covers, metal boxes, drums, and other materials (Anderson \& Liss, 2010). Anaerobic digestion was recommended especially for programs where collection was less frequent or where disposal costs were high (Anderson \& Liss, 2010). Anaerobic digestion may be a good processing type for cities where citizens are very concerned with odor because food scraps are locked in airtight containers (Layzer \& Schulman, 2014; Vaz, 2015). Also, anaerobic digestion produces clean energy; this method of clean energy production can create jobs and provide revenue (Vaz, 2015). However, 
people may be concerned that anaerobic digestion may cause explosions and release harmful gases (Vaz, 2015).

Nearby Processing Facility. Having a nearby processing facility for food scraps is vital to a RFSP, because if a facility is too far, the increased transportation costs may make a program too expensive. One option for cities is to create their own facilities, like Toronto, Canada (Layzer \& Schulman, 2014). Similarly, Hamilton, Massachusetts considered building their own facility, not just for having a facility in their vicinity, but also as a means of revenue; the facility would accept organics from other cities (Layzer \& Schulman, 2014). Another method to deal with far away facilities is by using and/or expanding transfer stations. For example, Denver, Colorado originally transported their organics from the city directly to a facility more than 40 miles away. Haulers were carrying loads less than half full 40 miles out. To save costs Denver then started to haul organic waste to a transfer station in the city; organics were ground up and held until loads became full then taken to the processing facility (Layzer \& Schulman, 2014).

\section{Solution Generation}

The different methods cities are using to comply with SB 1383 are summarized in Table 4. Information for each city was collected from hauler and city webpages on their garbage and recycling, Zero Waste, and food scrapping programs, which are listed in the References, and by speaking with city and hauler staff. Some cities had organic waste diversion efforts in place prior to SB 1383 due to their own adopted county or city policies. For the purpose of this report, “carts” refer to containers given to single family residences, and "bins” refer to the dumpsters at commercial and MFBs. The cart column in Table 4 indicates which cart a city’s food scraps go into. The bags column indicates which types of bags were allowed for food scraps collection. Also for the purpose of this report, a nearby facility is less than 40 miles away from the city 
because case studies in Layzer and Schulman's (2014) article found hauling waste 40 miles out to be too far and costly. Distances between cities and facilities were taken from Google Maps (2019); for each distance the city was inputted as the starting point, and the facility location (addresses looked up online) was inputted as the end point. 
Table 4

\begin{tabular}{|c|c|c|c|c|c|c|c|c|}
\hline & Population & \% College & $\begin{array}{c}\text { Median } \\
\text { Income }\end{array}$ & Program Name & Started & ZW & WP & Voluntary \\
\hline City & & & & & & & \\
\hline Cupertino & 60,777 & 77.2 & $\$ 153,449$ & NA & 2010 & $\checkmark$ & $\checkmark$ & Partial \\
\hline Livermore & 90,295 & 41.4 & $\$ 109,084$ & NA & 2014 & & $\checkmark$ & Partial \\
\hline Milpitas & 78,106 & 46.4 & $\$ 110,752$ & NA & 2017 & & $\checkmark$ & Partial \\
\hline Morgan Hill & 45,037 & 40.5 & $\$ 107,161$ & NA & NA & & $\checkmark$ & $\checkmark$ \\
\hline $\begin{array}{c}\text { Mountain } \\
\text { View }\end{array}$ & 81,438 & 67.2 & $\$ 120,351$ & Include Food & 2017 & $\checkmark$ & $\checkmark$ & \\
\hline $\begin{array}{c}\text { Palo Alto } \\
\text { San }\end{array}$ & 67,178 & 81.1 & $\$ 147,537$ & Zero Waste Program & 2015 & $\checkmark$ & $\checkmark$ & $\checkmark$ \\
\hline Francisco & 884,363 & 55.8 & $\$ 96,265$ & Zero Waste Program & 2000 & $\checkmark$ & $\checkmark$ & \\
\hline $\begin{array}{c}\text { San Jose } \\
\text { Santa Clara }\end{array}$ & $1,035,317$ & 41.3 & $\$ 96,662$ & NA & 2008 & $\checkmark$ & $\checkmark$ & $\checkmark$ \\
\hline Sunnyvale & 153,656 & 62.6 & $\$ 118,314$ & Food Cycle & 2017 & $\checkmark$ & $\checkmark$ & $\checkmark$ \\
\hline
\end{tabular}

Table 4 (continued).

\begin{tabular}{|c|c|c|c|c|c|c|c|c|}
\hline & Cart & Pail & $\begin{array}{c}\text { Separate } \\
\text { Fee }\end{array}$ & Fine & Bags & $\begin{array}{l}\text { Soiled } \\
\text { Paper }\end{array}$ & MFB & $\begin{array}{c}\text { End } \\
\text { Product }\end{array}$ \\
\hline \multicolumn{9}{|l|}{ City } \\
\hline Cupertino & Compost Cart & $\checkmark$ & & & Compostable & $\checkmark$ & $\checkmark$ & Compost \\
\hline Livermore & Organics Container & $\checkmark$ & & & None & $\checkmark$ & $\checkmark$ & Compost \\
\hline Milpitas & Split & $\checkmark$ & & & Any plastic & $\checkmark$ & $\checkmark$ & $\begin{array}{l}\text { Animal } \\
\text { Feed }\end{array}$ \\
\hline Morgan Hill & With yard waste & & & & NA & NA & NA & NA \\
\hline $\begin{array}{c}\text { Mountain } \\
\text { View }\end{array}$ & Compost Cart & $\checkmark$ & & & Compostable & $\checkmark$ & $\checkmark$ & Compost \\
\hline Palo Alto & Green Cart & $\checkmark$ & & & Compostable & $\checkmark$ & $\checkmark$ & $\begin{array}{c}\text { Compost } \\
\& \\
\text { Renewable } \\
\text { Energy }\end{array}$ \\
\hline $\begin{array}{c}\text { San } \\
\text { Francisco }\end{array}$ & Compost Cart & $\checkmark$ & & $\checkmark$ & Compostable & $\checkmark$ & $\checkmark$ & Compost \\
\hline San Jose & Garbage Cart & & & & Any & $\checkmark$ & $\checkmark$ & Compost \\
\hline Santa Clara & Split & $\checkmark$ & & & Any clear & & $*$ & $\begin{array}{c}\text { Animal } \\
\text { Feed }\end{array}$ \\
\hline Sunnyvale & Split & $\checkmark$ & & & Any clear & & $*$ & $\begin{array}{c}\text { Animal } \\
\text { Feed and } \\
\text { Energy }\end{array}$ \\
\hline
\end{tabular}

*Demographic information taken from the United States Census Bureau (n.d.a, n.d.b, n.d.c, n.d.d, n.d.e, n.d.f, n.d.g, n.d.h, n.d.i, n.d.j)

Table 4 Key

\begin{tabular}{|l|l|}
\hline \% College & \% of Population with a bachelor's or more \\
\hline ZW & City has adopted a Zero Waste Policy/Program \\
\hline WP & Organics are picked up weekly \\
\hline Pail & Residents provided with an organics collection container for their kitchens \\
\hline $\begin{array}{l}\text { Soiled } \\
\text { Paper }\end{array}$ & Items such as pizza boxes, used paper plates and so on allowed with organics \\
\hline MFB & Organic waste collected from multifamily housing buildings \\
\hline
\end{tabular}


The City of Cupertino. Cupertino, California is the second smallest, second most educated, and has the highest median income of all the cities researched in this report. The city's waste diversion goals exceed SB 1383 requirements due to the city's adopted Zero Waste Policy; their goal is to have a minimum diversion rate of $75 \%$ and to meet and maintain an $80 \%$ diversion rate by 2025 (City of Cupertino, 2017). Although the Zero Waste Policy was adopted in 2017, the practice of adding food scraps to yard trimmings started in 2010 for single-family homes (L. Dickinson, personal communication, February 6, 2019). Multifamily homes have had the opportunity to subscribe to organic waste services since 2013; these services were required starting in July 2018 (L. Dickinson, personal communication, February 6, 2019). Compost cart regulation and fines may be put in place in the future due to SB 1383 (L. Dickinson, personal communication, February 6, 2019).

In addition to encouraging residents and businesses to divert waste, the city also encourages its people to reduce the amount of waste generated. The City of Cupertino explains on their garbage and recycling website that practicing the three R's (reduce, reuse, and recycle) helps the environment by reducing air, soil, and water pollution, GHG emissions, and the amount of resources required for producing and transporting goods (City of Cupertino, 2019c). Cupertino’s curbside waste services are implemented by Recology, a waste management company that specializes in recovery of recyclable and organic materials with locations throughout California, Oregon, Nevada, and Washington (City of Cupertino, 2019c; Recology, n.d.a). Organics from carts go to South Valley Organics, in Gilroy, California (40 miles from Cupertino); and organics from bins go to Blossom Valley Organics in Vernalis, California (about 72 miles out) (L. Dickinson, personal communication, February 6, 2019). 
See Table 5 for a summary of the smart practices that Cupertino implements. Cupertino's webpages have sufficient educational information on how to sort waste and compost, and why it is important to do so (City of Cupertino, 2019a, 2019b, 2019c). Their outreach efforts were not found. Thrown away food is referred to as "waste" once on one of the city's webpages (City of Cupertino, 2019c) and on their Zero Waste Policy (City of Cupertino, 2017); although, the majority of their webpage content uses "scraps" instead of "waste." Cupertino partners with at least two community agencies; Recycle Stuff (City of Cupertino, 2019c) and the University of California's Cooperative Extension (UCCE) (City of Cupertino, 2019a). Recycle Stuff is a nonprofit that serves Santa Clara and San Mateo County; they are part of San José State University. They provide information on where to recycle almost any material (Recycle Stuff, 2018). The Composting Education Program is executed by the UCCE. The program partners with Santa Clara County cities to educate communities on composting (UCCE, 2019).

Table 5

\begin{tabular}{|l|l|}
\hline Smart Practices Implemented by Cupertino, CA & Additional Information \\
\hline Public outreach and education & Through webpages and nonprofits \\
\hline Policies that enforce organic diversion & Zero Waste Policy \\
\hline Financial Incentives & Has a PAYT system, (Residential Rate Schedule, n.d.). \\
\hline Pre-existing infrastructure and/or yard waste program & Cupertino had a yard waste program \\
\hline Does not use the term, “Food Waste” & \\
\hline Use only 1 or a few haulers & Recology \\
\hline Partner with nonprofits and the community & Recycle Stuff \& UCCE \\
\hline
\end{tabular}

City of Livermore. Livermore, California is one of the smaller cities analyzed. In Livermore, food scraps are mixed with yard waste in an organics cart (Livermore Recycles, 2018b). Single family homes are required to subscribe to the three different carts (garbage, 
organics, and recycling) but are not required to use the organics and recycling ones. MFBs are required to subscribe to the three bins and to sort their waste properly (M. Gan, personal communication, February 6, 2019). Their garbage and recycling programs are run by Livermore Sanitation; organics are taken to a compost facility in Vernalis, California to be turned into compost (M. Gan, personal communication, February 6, 2019). Livermore Sanitation uses a PAYT system for non-diverted waste; all their rates include a 96 gallon organics cart but customers can request smaller ones (Livermore Sanitation, 2019).

See Table 6 for a summary of the smart practices that Livermore uses. Livermore practices public outreach and education through Livermore Recycles, a program from the city’s Public Works Department. Livermore Recycles has a mascot in the form of an organics cart called Binny (Livermore Recycles, 2018a). Their website provides educational material in the form of videos (one video is in Spanish), comics, and pictures (Livermore Recycles, 2018a, 2018b). There is a webpage dedicated to teaching residents about which items go in the organics cart (Livermore Recycles, 2018b). Alameda County has a policy that requires MFBs to divert organic waste (Alameda County Waste Management Authority, n.d.).

Table 6

\begin{tabular}{|l|l|}
\hline Smart Practices Implemented by Livermore, CA & Additional Information \\
\hline Public outreach and education & Through Livermore Recycles \\
\hline Policies that enforce organic diversion & $\begin{array}{l}\text { Through Alameda County's policy that requires MFBs } \\
\text { and Businesses to divert organic waste }\end{array}$ \\
\hline Financial incentives & $\begin{array}{l}\text { Organic cart included in cost of black cart; PAYT } \\
\text { system used }\end{array}$ \\
\hline Pre-existing infrastructure and/or yard waste program & \\
\hline Does not use the term, “Food Waste” & \\
\hline Use only 1 or a few haulers & Livermore Sanitation \\
\hline Nearby Processing Facility & 33 miles from Livermore, CA \\
\hline
\end{tabular}


City of Milpitas. The curbside waste system for the City of Milpitas in California is run by Milpitas Sanitation (Milpitas Sanitation, 2019a), a partner company of Garden City Sanitation (Milpitas Sanitation, 2019c). Milpitas uses three different carts: a split solid waste/food cart, a split recyclables cart (one side for recyclable containers, the other for papers and fibers), and a yard trimmings cart (Milpitas Sanitation, 2019b). Food scraps are taken to a SAFE processing facility in Santa Clara to be turned into animal feed, and yard trimmings are taken to the Z-Best Composting facility to be made into compost (Milpitas Sanitation, n.d.b; U. Mai, personal communication, February 6, 2019). The SAFE facility is less than 10 miles from Milpitas (SAFE, 2016), and Z-Best is about 42 miles out. Z-Best Composting is a composting facility located in Santa Clara County near Gilroy; it opened in 1997 for yard waste processing (Z-Best Composting, n.d.). Milpitas’ organic waste diversion efforts have increased due to SB 1383 (U. Mai, personal communication, February 6, 2019).

All single family households are required to subscribe to the solid waste/food split cart; however, they can choose the size of their carts (other carts and kitchen pail provided at no additional cost) (Milpitas Sanitation, 2019b). See Appendix B for different split cart size offerings and rates for Milpitas. By being able to choose one of four different sizes, residents choose how much they pay for curbside waste services; this system is designed in a way where the more waste diverted, the less residents pay (Milpitas Sanitation, n.d.a; U. Mai, personal communication, February 6, 2019). MFBs are encouraged but not required to subscribe to the garbage/food scrap split cart; however, the subscription will save them curbside services costs (U. Mai, personal communication, February 6, 2019).

See Table 7 for a summary of the smart practices that Milpitas uses. The city provides public education in the form of various informative videos on topics such as organic waste 
processing and how to use all the waste carts (Milpitas Sanitation, 2019d). Various links to other websites and resources are also provided which teach residents about composting, where to donate, and other related topics (Milpitas Sanitation, 2019d). Public outreach practices were not found while researching the city.

\section{Table 7}

\begin{tabular}{|l|l|}
\hline Smart Practices Implemented by Milpitas, CA & Additional Information \\
\hline Public education & \\
\hline Policies that enforce organic diversion & All single-family homes required to participate \\
\hline Financial incentives & PAYT system \\
\hline Pre-existing infrastructure and/or yard waste program & \\
\hline Does not use the term, “Food Waste” & \\
\hline Use only 1 or a few haulers & Milpitas Sanitation \\
\hline Nearby Processing Facility & SAFE processing facility less than 10 miles away \\
\hline
\end{tabular}

City of Morgan Hill. Morgan Hill, California is the smallest city researched. The City of Morgan Hill, along with the City of Gilroy, California, collects food waste from residents that are mixed in with yard waste; this has been in practice for several years (A. Eulo, personal communication, February 4, 2019). The city relies on residents' voluntary participation and good will for its recycling programs (City of Morgan Hill, n.d.a). The city anticipates that SB 1383 will have a negative financial impact on residents (A. Eulo, personal communication, February 4, 2019). Waste services are implemented by Recology South Valley (City of Morgan Hill, n.d.b); a company with goals of waste diversion from landfills and using diverted organics for compost (Recology, n.d.c, n.d.f). Recology’s South Valley Organics facility in Gilroy is only about 12 miles out and accepts food scraps and yard trimmings (Recology, n.d.e). However, it was not clear which facility organics from Morgan Hill were sent to. 
City of Mountain View. The City of Mountain View, California has a goal of Zero Waste; therefore, their waste diversion goals exceed the goals of SB 1383. Specifically, the city has a goal to divert $90 \%$ of waste from landfills; their diversion rate at the time of this report was 78\% (City of Mountain View, n.d.a). Their RFSP is called, “Include Food” (City of Mountain View, n.d.a). Food scraps and food soiled paper are mixed with yard trimmings; the yard trimmings cart was renamed to the compost cart (City of Mountain View, n.d.a). Kitchen pails are provided to residents with individual compost carts (J. McCurdy, personal communication, February 7, 2019). Single family and MFBs (one to eight residential units) may subscribe to Mountain View's RFSP. A pilot RFSP began for larger MFBs (properties with nine or more units) in October, 2018; the program will be evaluated for feasibility, appropriate costs and rates (City of Mountain View, n.d.a).

In addition to curbside RFSPs, Mountain View also had plans to begin their Recycling Center Food Scraps Pilot in February, 2019. This program will be available to residents who have signed up; they will be able to drop off food scraps in compostable bags at the Mountain View Recycling Center (City of Mountain View, n.d.a). What is unique about Mountain View is that although residents pay waste fees depending on the size of their trash cart, the trash cart is dependent on household size; residents cannot choose based on which is the most inexpensive option (City of Mountain View, n.d.b.). Mountain View is aiming to meet 50\% and 75\% reduction in organics by 2020 and 2025 (J. McCurdy, personal communication, February 7, 2019), which reflect SB 1383 goals.

On their RFSP webpage, the City of Mountain View educates the public on the benefits of composting and zero waste. The waste from the compost carts are taken to the SMaRT Station in Sunnyvale (five to seven miles out) for processing: The SMaRT Station processes and 
transfers material between Mountain View, Sunnyvale, and Palo Alto. After initial processing, the materials are taken to Recology's compost facility in Gilroy. Most of the compost developed is used for home landscaping projects (City of Mountain View, n.d.a). Although Gilroy is about 44 miles away, the SMaRT Station acts as a transfer station; materials are compacted, and trucks can wait until there are full loads. See Table 8 for a summary of smart practices used. No public outreach efforts or partnerships with nonprofits and the community were found. However, the city adequately provides instructions and details on sorting waste, the importance of waste diversion, the composting process, and other information.

Table 8

\begin{tabular}{|l|l|}
\hline Smart Practices Implemented by Mountain View, CA & Additional Information \\
\hline Public outreach and education & $\begin{array}{l}\text { Educational material on why and how to sort food } \\
\text { scraps and other waste, program is branded }\end{array}$ \\
\hline Policies that enforce organic diversion & Zero Waste Policy \\
\hline Pre-existing infrastructure and/or yard waste program & $\begin{array}{l}\text { The city has planned pilots for MFBs and a drop off } \\
\text { site }\end{array}$ \\
\hline Pilots & \\
\hline Does not use the term, "Food Waste” & Recology \\
\hline Use only 1 or a few haulers & SMaRT Station is less than 10 miles away \\
\hline Nearby Processing Facility & \\
\hline
\end{tabular}

City of Palo Alto. Palo Alto, California is one of the smaller cities analyzed; it is also the most educated and has the second highest median income. Their organic waste diversion efforts are embedded in their Zero Waste mission. Their Zero Waste plan was adopted in 2007 and updated in 2018. Palo Alto’s City Council has adopted goals of 95\% diversion of waste and 80\% reduction in GHGs by 2030; the city recognized that organic waste diversion had to be implemented to achieve these goals (City of Palo Alto, 2018). Businesses and MFBs were given the option of adding food scraps to their compost bins in 2009; the service was expanded to 
single family homes in 2015. In 2016, a city ordinance required commercial and MFBs to include all three waste streams (garbage, recycling, and compost) (W. Hediger, personal communication, February 7, 2019). Curbside waste services are provided to Palo Alto by GreenWaste of Palo Alto. Food scraps are mixed with yard trimmings in compost carts (City of Palo Alto, 2019b).

Organic materials are processed at the Zero Waste Energy Development Corporation anaerobic digestion facility which produces renewable energy to operate the facility. Excess energy produced at the facility is sold to the power grid. The materials leftover from the digestion process are further composted at the Z-Best compost facility. The City also partners with the cities of Mountain View and Sunnyvale on the Sunnyvale Materials Recovery and Transfer Station (SMaRT Station). The SMaRT Station processes mixed garbage from Palo Alto and recovers recyclable and compostable materials that would have otherwise gone to landfill (City of Palo Alto, 2018, p. 5).

Palo Alto provides information on diversion rates and disposed pounds of solid waste per person per day from 2007 to 2017. In 2017 their diversion rate was 80\%; residents generated roughly 3.8 pounds of waste per day which was lower than the state average (state average in 2016 was six pounds of waste per person per day) (City of Palo Alto, 2019a). Palo Alto uses a PAYT system (“Attachment E,” 2017).

In an effort to capture food scraps, Palo Alto had a two-cart pilot program from 2013 to 2014 (City of Palo Alto, 2014). In this program, instead of the traditional black (garbage), blue (recyclables), and green (yard trimmings) carts, only two carts were used. The blue cart was used for garbage and recyclables, and the green cart was used for yard trimmings, food scraps, and food soiled papers. The black cart was not to be used at all. Trash was to be put in bags, except 
for large items that were to be put in loose. Food scraps and soiled papers were to be put in compostable bags, except for large items such as pizza boxes which would go in loose (City of Palo Alto, 2014). The program had a high participation rate of 65\%, and residential diversion rates increased by $8 \%$. An average of 1,280 pounds of food scraps were collected each week. However, the pilot neighborhood size was too large for the program; sometimes trucks had to make second trips to the drop off site. Items such as diapers and pet waste contaminated salvageable materials. Additionally, residents did not like purchasing compostable bags and found sorting waste into different carts confusing; this ultimately halted expansion of the program (City of Palo Alto, 2014). The City of Palo Alto does not have plans of resuming the two-cart system or implementing another food scrap program at this time (W. Hediger, personal communication, February 7, 2019).

See Table 9 for a summary of the city's smart practices. Palo Alto’s outreach programs include (1) Zero Waste Block Leaders and Champions, (2) Green Teams, (3), New resident welcome, and information, (4) What Goes Where annual outreach, and others. The outreach programs target residents and schools (City or Palo Alto, 2018). Palo Alto offers sorting guides, posters, videos, and even a game on their website (City of Palo Alto, 2019b). There is also information on the composition of Palo Alto's garbage; it shows residents the percentages of materials that can be diverted that have been found in the trash (City of Palo Alto, 2019a). Palo Alto's compostable waste can be processed at three facilities. The first facility is in San Jose which is roughly 15 miles away; leftover material from processing in San Jose is taken to Z-Best in Gilroy which is about 52 miles out. Compostables may also be taken the SMaRT Station (City of Palo Alto, 2018), which is only 11 miles out. 
Table 9

\begin{tabular}{|l|l|}
\hline Smart Practices Implemented by Palo Alto, CA & Additional Information \\
\hline Public outreach and education & \\
\hline Policies that enforce organic diversion & Zero Waste Policy \\
\hline Financial Incentive & PAYT system \\
\hline Pre-existing infrastructure and/or yard waste program & \\
\hline Use only 1 or a few haulers & GreenWaste of Palo Alto \\
\hline Partners with nonprofits and the community & $\begin{array}{l}\text { Partners with the community for outreach and } \\
\text { education }\end{array}$ \\
\hline Nearby Processing Facility & 2 of 3 facilities are 11-15 miles out \\
\hline
\end{tabular}

County and City of San Francisco. San Francisco, California, the second largest city researched for this report, is well known for its progressive waste management methods. The city’s organic waste diversion efforts are due to their Zero Waste Program. It is the only city in this report where composting and diverting organic waste is mandatory for all residents (SF Environment, 2019a); fines are given for cart contamination (Recology, n.d.d), although it is unclear how much residents are fined. San Francisco’s trash hauler is Recology; curbside services are implemented by Recology as well as the Public Works, Environmental, and Public Health Departments (SF Environment, 2019c). Three standard carts are used: (1) a 32 gallon green compostable cart for yard trimmings, soiled paper, and food scraps, (2) a 64 gallon blue recycling cart, and (3) a 16 gallon black cart for items headed for a landfill (Recology, n.d.b, n.d.g; SF Environment, n.d.b). San Francisco calls their three waste bin system the "Fantastic Three” (SF Environment, 2019c). Items in the black cart are not sorted by any hauler or facility; it is up to residents to properly sort their waste (SF Environment, 2019a). Compost and trash are picked up by split chamber trucks, and recyclables are collected by a larger single chamber truck (Recology, n.d.g). The rates for curbside waste services are designed in a way where residents 
save money by using smaller black carts (Recology, n.d.b). Food scraps are sent to a facility near Vacaville, California to be turned into compost (SF Environment, 2019a).

San Francisco provides information on costs, best practices, wins, and challenges that they have come across throughout their Zero Waste Program. The Zero Waste Program is funded through curbside services fees; the fees cover everything from material collection and processing to outreach and marketing (SF Environment, 2019c). San Francisco’s Environmental Department, also known as SF Environment, executes various methods of education and outreach, such as multilingual and door to door outreach services to businesses and residents (SF Environment, 2019c). SF Environment prefers to educate rather than use fines to make residents compliant with the city's waste and recycling ordinances; warning tags and outreach are used first (SF Environment, 2019c). What is unique to San Francisco is that government officials are seen as ambassadors of the program and are expected to lead by example (SF Environment, 2019b).

The city boasts having the highest materials recovery rate of any major city in Northern America (SF Environment, 2019c); they reached a diversion rate of 80\% in 2012 (EPA, 2019b; SF Environment, n.d.a). Another win for the city’s Zero Waste Program is the creation of jobs; Recology employs at least 1,050 employees just in San Francisco, and SF Environment has a program that employs local residents for education and outreach on zero waste and other SF Environment programs (SF Environment, 2019c). The biggest challenges the city faces are trash chutes and the disgust residents feel about food scrapping. Many residents live in apartments with only one main trash shoot; they must walk other waste down to the appropriate containers. The city now has a policy that new apartment buildings must have a three chute system; they also encourage apartment landlords to close their chutes. Regarding the disgust factor, the city 
reminds residents that the same smelly food scraps are still present, but are now sorted in a separate container (SF Environment, 2019c).

One source said that organics were taken to a nearby facility (SF Environment, 2019c) and another source said food scraps were taken to Vacaville, California (SF Environment, 2019a) which is roughly 55 miles away, so it is unclear if the processing facilities are nearby or not. Although San Francisco does not appear to partner with nonprofits, they have created multiple programs and tools to promote waste diversion such as Recycle Where and SF Recycles, which are online portals that tell residents how to dispose of any material (SF Environment, 2019c). The city partners with the community by employing local residents from diverse backgrounds to teach communities about zero waste (SF Environment, 2019c). See Table 10 for a summary of San Francisco’s smart practices.

Table 10

\begin{tabular}{|l|l|}
\hline $\begin{array}{l}\text { Smart Practices Implemented by San Francisco, } \\
\text { CA }\end{array}$ & Additional Information \\
\hline Public outreach and education & Zero Waste Policy \\
\hline Policies that enforce organic diversion & PAYT system \\
\hline Financial Incentive & \begin{tabular}{l} 
Recology \\
\hline Pre-existing infrastructure and/or yard waste program \\
\hline Does not use the term, “Food Waste” \\
\hline Use only 1 or a few haulers \\
\hline Partners with nonprofits and the community
\end{tabular} \\
\hline
\end{tabular}

City of San Jose. San Jose, California is the largest city analyzed. The EPA recognizes the city for leading the nation in waste management and for having one of the highest diversion rates in the country at 74\% (EPA, 2019c). In 1991, the city was divided into three unequal parts to allow large and small waste management companies to bid for contracts; these companies 
were encouraged to work together and with nonprofits to meet waste management goals.

Although San Jose was able to create opportunities for smaller waste companies and experienced cost savings due to a more competitive market, managing all the agreements required more staff and increased workloads (EPA, 2019c). San Jose adopted a Zero Waste Program in 2007 with goals of diverting 75\% of waste by 2013 and 90\% or more by 2022 (Romanow, 2017). Like San Francisco, San Jose’s Zero Waste Program efforts have created jobs and increased diversion rates (EPA, 2019c).

The city is unique because unlike all the other cities mentioned in this report, food scraps and soiled papers are separated from landfill destined garbage at the facility rather than by residents; food scraps are not allowed in the yard trimmings cart (City of San Jose, n.d.a, n.d.b). Organic waste is recovered at GreenWaste’s Materials Recovery Facility (MRF) and turned into compost at the Z-Best facility in Gilroy (A. Lowrie, personal communication, February 15, 2019; City of San Jose, n.d.a; GreenWaste, 2019). The MRF acts as a transfer station (GreenWaste, 2016). The city began separating organics from garbage in 2008 beginning with MFBs, then in 2014 for single family homes. As of 2017, all single family homes’ garbage is processed in this manner (A. Lowrie, personal communication, February 15, 2019).

San Jose found that separating organics at the facility rather than by residents has resulted in more organic waste diversion (A. Lowrie, personal communication, February 15, 2019). The garbage rates in San Jose are designed to reward residents for diverting more waste; it is a PAYT system (EPA, 2019c). Haulers used in San Jose include Garden City Sanitation, GreenWaste, California Waste Solutions, and Green Team (Romanow, 2017). San Jose has four MRFs and five landfills within the city; these facilities are considered to be some of the most advanced in the country and serves as benchmarks for other cities (Romanow, 2017). San Jose does not own 
any of these landfills or facilities, and there is only one tipping fee for all MSW (A. Lowrie, personal communication, March 13, 2019). San Jose has the largest anaerobic digestion facility in the world but it is only used for commercial waste (A. Lowrie, personal communication, March 13, 2019).

Although San Jose does not collect food scraps separately from residents, the city had a RFSP pilot back in 2015, called The San Jose Residential Food Scraps Pilot Program, which was implemented by Garden City Sanitation (Montgomery, n.d.; Romanow, 2016). The pilot was meant to last one year (Montgomery, n.d.; Romanow, 2016) but lasted from September, 2015 to March, 2018 (A. Lowrie, personal communication, February 15, 2019). Two different methods were tested. A 64 gallon split cart was given to about 2,800 households: 46 gallons for garbage and 18 gallons for food scraps. About 3,800 households were given a 20 gallon food scrap cart in addition to their standard containers (garbage, yard trimmings, and recycling carts). Participation was voluntary and collection days did not change. Kitchen pails were distributed to the homes. Fines and MFBs were not mentioned. Food soiled paper was not accepted although any type of bag for collection of food scraps was allowed. Food scraps were given to SAFE to make animal feed (Montgomery, n.d.; Romanow, 2016).

Outreach began with informative postcards being mailed to the homes in the pilot neighborhoods along with informative cart hangers and kitchen pails (Montgomery, n.d.). Midpilot results showed that households with the separate food scrap bin participated at a 35\% rate, and 15 pounds of materials were collected from each household per week. The split cart method had a $65 \%$ participation rate with 11 pounds of materials being collected each week. Approximately, 110 households opted out of the pilot program (Montgomery, n.d.). The city ultimately decided to discontinue their RFSP due to cost, sub-optimal pilot results, and not being 
able to come to an agreement with different haulers on a feasible citywide program during contract negotiations (A. Lowrie, personal communication, February 15, 2019). The city currently does not have plans for resuming their RFSP or creating a new one (A. Lowrie, personal communication, February 15, 2019).

See Table 11 for a summary of San Jose’s smart practices in use. Information on how to recycle is given in English, Spanish, and Vietnamese online (City of San Jose, n.d.b). San Jose's garbage and yard trimmings are first processed at GreenWaste’s MRF in San Jose. Recovered organics from garbage and yard trimmings are then taken to Z-Best in Gilroy for further processing (GreenWaste, 2016, 2019). San Jose addresses overall general and food waste reduction in addition to recycling. The city has partnered with Santa Clara County and its other cities, the San Jose Earthquakes, and the Bay Area Recycling Outreach Coalition for public outreach on reuse and food waste reduction (Romanow, 2017). San Jose does not allow ADCs to be considered as organic waste diversion (EPA, 2019c).

Table 11

\begin{tabular}{|l|l|}
\hline Smart Practices Implemented by San Jose, CA & Additional Information \\
\hline Public outreach and education & Education on sorting waste \\
\hline Policies that enforce organic diversion & Zero Waste Policy \\
\hline Financial Incentive & PAYT system \\
\hline Pre-existing infrastructure and/or yard waste program & \\
\hline Partner with nonprofits and the community & \\
\hline Nearby Processing Facility & Initial processing is done within the city \\
\hline Forbid ADCs & \\
\hline
\end{tabular}

City of Santa Clara. Santa Clara, California is currently implementing a pilot RFSP, called the Food Scrap Recycling Program, that began in October, 2017. It will run for four years; the program will either be discontinued or expanded to the rest of the city depending on pilot 
results (Environmental Programs Staff of the CSC, personal communication, February 6, 2019). Their RFSP is in response to SB 1383 (CSC, 2019). Curbside waste services are provided by Recology South Bay (recycling) and Mission Trail (garbage and green waste) (CSC, n.d.a). Mission Trail is also Santa Clara’s hauler for their RFSP (CSC, 2019).

Around 4,800 households (single family and small MFBs) on two different routes are part of the pilot. Participants were notified by mail and given a split garbage can (garbage and food scraps), kitchen pail, a starter supply of plastic bags for kitchen pail liners, and instructional material. Garbage and food scraps are collected by a garbage truck with a split chamber. Food scraps are taken to a SAFE facility within the city for processing (CSC, 2019). The city uses a PAYT system for non-diverted waste (CSC, 2018). The city provides the results of two RFSP surveys on their website; one survey was distributed and collected in December, 2017, and the other in June, 2018. There were 1,402 respondents for the first survey, and 1,254 for the second. The surveys indicated that about $82-86 \%$ of respondents were participating in the program by using the food scrap side of their garbage carts (CSC, n.d.b, n.d.c, 2019).

See Table 12 for a summary of the city’s smart practices. Santa Clara’s webpages regarding their RFSP provides clear instructions on how the program works and how to use it properly. Public outreach is minimal; outreach did not seem to continue after the introductory kits were sent. 
Table 12

\begin{tabular}{|l|l|}
\hline Smart Practices Implemented by Santa Clara, CA & Additional Information \\
\hline Public outreach and education & Clear program details and instructions provided \\
\hline Financial Incentive & PAYT system \\
\hline Pre-existing infrastructure and/or yard waste program & \\
\hline Pilot program & Started 2017, will last 4 years before expansion \\
\hline Does not use the term, “Food Waste” & \\
\hline Uses 1 or a few haulers & Mission Trail and Recology South Bay \\
\hline Nearby processing facility & Within the city \\
\hline
\end{tabular}

City of Sunnyvale. Sunnyvale, California has a RFSP called FoodCycle; the program provides residents of single family and mobile homes split garbage cans (garbage and food scraps). FoodCycle was created in response to SB 1383 and the city’s Zero Waste Plan, which was adopted in 2013 (City of Sunnyvale, 2019a). The program was expanded city wide in 2018 after a pilot program demonstrated a participation rate of $73 \%$ and a food capture rate of $62 \%$ (City of Sunnyvale, 2019a). The pilot program was conducted in 2015 and served roughly 500 homes (City of Sunnyvale, 2019b). Residents of MFBs have the option of dropping off food scraps at the SMaRT station in Sunnyvale. Kitchen pails are provided to households with individual split garbage carts, other residents can obtain a kitchen pail from the SMaRT station or city hall with proof of residence.

FoodCycle and other curbside waste services are provided by Specialty Solid Waste and Recycling (SSWR) (City of Sunnyvale, 2019b; SSWR, 2017). Individual split carts are emptied into garbage trucks with split chambers. Food scraps are taken to the SMaRT station (acting as a transfer station) where food is made into a liquid mash. The liquid mash is taken to Sustainable Organic Solutions in Santa Clara, California where it is turned into animal feed ingredients. At times when the facility in Santa Clara cannot accept the liquid mash, it is taken to the East Bay 
Municipal District in Oakland, California for anaerobic digestion to be turned into energy for the plant (City of Sunnyvale, 2019b). As of November, 2018, roughly 3,600 tons of residential food scraps were diverted, garbage going to the landfills decreased by $18 \%$, and waste management costs decreased by $\$ 360,000$ (City of Sunnyvale, 2019a). The city uses a PAYT system for nondiverted waste (City of Sunnyvale, n.d.).

The city practices the most found smart practices; see Table 13 for a summary. Public outreach is minimal if any. The city's websites contain clear and detailed instructions on how to sort their waste in English, Spanish, and Chinese. There is also a tool available, called "How to Get Rid of Anything," where residents can type in any material and learn how to dispose of it (City of Sunnyvale, 2019c). There was no indication that the city partners with nonprofits or the community for outreach and education purposes.

Table 13

\begin{tabular}{|l|l|}
\hline Smart Practices Implemented by Sunnyvale, CA & Additional Information \\
\hline Public education & $\begin{array}{l}\text { Clear program details and instructions provided, } \\
\text { program is branded }\end{array}$ \\
\hline Policy & Zero Waste \\
\hline Financial Incentive & PAYT system \\
\hline Pre-existing infrastructure and/or yard waste program & \\
\hline Pilot program & Implemented in 2015 \\
\hline Does not use the term, “Food Waste” & \\
\hline Uses 1 or a few haulers & Specialty Solid Waste \& Recycling \\
\hline Nearby processing facility & Transfer Station within the city \\
\hline
\end{tabular}




\section{ANALYSIS \& DISCUSSION}

The analysis discusses organic waste diversion efforts of each city and which smart practices, if any, a city should or should not pursue. Because the evaluation was done mostly externally, information on which smart practices cities implement may not be complete. For example, of all the cities analyzed, it was not known if political support or grants were pursued prior to the creation of food scrap programs. Additionally, because all the cities discussed in this report use contractors for waste hauling and processing, and take their waste to other cities, smart practices such as higher tipping fees for inorganic waste, simplifying permit processing, use of anaerobic digestion, forbidding ADCs, and considering future costs of landfills were usually not applicable. Every city analyzed used weekly pick up of all carts (garbage, compostables, and recyclables). If program costs are an issue, a city can consider reducing pickups by alternating weekly service of two different carts, or pick up non-diverted waste every other week (Anderson \& Liss, 2010; Layzer \& Schulman, 2014). Reduced pickups may also motivate residents to divert more waste.

The City of Cupertino. Cupertino, California is currently in compliance with SB 1383 because they have active programs that are diverting organic waste from landfills. The city has curbside composting and through a nonprofit, teaches willing residents to compost at their homes (City of Cupertino, 2019a). If the city adds penalties and ensures that at least $75 \%$ of organic waste is being diverted, they may be compliant with SB 1383 indefinitely. It appears the city is headed toward a high organic diversion rate as their Zero Waste Policy goals include reducing food waste and then redirecting food waste according to the EPA's FRH, and to "Ensure that facilities, infrastructure, and outreach are in place to enable all people in Cupertino to divert all discarded materials correctly and entirely. Properly manage all recovered materials and continue 
to provide incentives and public training to support proper and effective backyard composting” (City of Cupertino, 2017, p. 2).

To improve program costs, Cupertino should look into a closer organics processing facility; current facilities are 40 plus miles out. The city can look into the facilities used by similar and nearby cities such as Mountain View, Palo Alto, and Sunnyvale. If none are available, the city should consider making their own composting facilities or digesters. Having their own facilities would eventually decrease transportation costs, create jobs, and may give the city revenue if other cities use their plants or if they sell the developed compost or energy. In any case, investing in a nearby facility should be considered, especially since Cupertino is planning on making organic waste diversion a significant and permanent change.

City of Livermore. Livermore, California is actively diverting organic waste from landfills, however it is not known if they will meet SB 1383 requirements in the future since they do not require single family homes to divert waste, and there were no goals or measures found. Layzer and Schulman (2014) found that in 2012 Alameda County diverted more than 180,000 tons of residential organics (food and yard waste); however only 5-10\% was made up of food scraps. Coupled with commercial and MFB organic waste diversion, the county (and perhaps by extension Livermore) may be on their way to meeting SB 1383 goals. However, having an additional policy that requires residents of single family homes and smaller MFBs to divert food scraps and yard waste would increase organic waste diversion. Pursuing political support by educating stakeholders would be a smart first step towards creating this policy. However, before Livermore adopts such a policy, they should determine how much more organics the processing facility they currently use can take. Capacity was a common problem for creating and implementing RFSPs (Layzer \& Schulman, 2014). 
City of Milpitas. The city is SB 1383 compliant because they have an active RFSP. It is likely they will meet the diversion goals of SB 1383 because their organic waste diversion programs have been created specifically to address AB 1826 and SB 1383. Smart practices that the City of Milpitas can pursue are using nonprofits or the community for public outreach and finding a closer facility for yard trimming processing if finances become an issue.

City of Morgan Hill. The City of Morgan Hill has minimal organic waste diversion efforts in addition to efforts to comply with AB 1826 (A. Eulo, personal communication, February 4, 2019); food scraps may be mixed with yard waste if an individual chooses to do so (City of Morgan Hill, n.d.a). It is recommended that political stakeholders, such as the Environmental Services Department and then the City Council, be educated on the benefits of large-scale organic waste diversion and requirements of SB 1383. Eventually a policy should be created that requires residents to properly sort waste (commercial entities are already covered by AB 1826). Because costs were a major concern, Morgan Hill should pursue grants to assist in their organic waste diversion efforts. The city should check back with CalRecycle periodically to look for grant opportunities.

Another cost saving smart practice that Morgan Hill can implement is using a PAYT system for landfill directed waste and offering significantly lower prices for yard waste cart service. The city can also reduce the pick-up of non-diverted waste to once every other week while keeping their other carts on a weekly pick up schedule. Morgan Hill can use a pilot program on a fraction of the city to see how residents react, or whether they are satisfied with the reduced pick up schedule and price scales. The city can look into using nonprofits (such as UCCE) or community members who are passionate about composting to teach Morgan Hill residents and local government officials on how to compost or divert waste (while gaining 
support); research has shown that just a few people can make a significant impact (Layzer \& Schulman, 2014).

Morgan Hill is in an ideal position to have a food scrap policy because they already have an infrastructure (their yard waste program), their hauler is already familiar with organic waste diversion (Recology, n.d.c, n.d.f), and they have nearby organics processing facilities in Gilroy (Z-Best and South Valley Organics). The city should contact Recology South Valley and the South Valley Organics facility to determine capacity allowances and to discuss starting a pilot program.

City of Mountain View. The city's organic waste diversion goals are aiming to meet SB 1383’s waste diversion goals of 50 and 75\% reduction by 2020 and 2025; they also have an ambitious zero waste program. They have multiple residential organic waste diversion efforts such as their RFSP for single family homes and small MFBs, a RFSP for larger MFBs, and a drop off site available to any resident (City of Mountain View, n.d.a). To increase organic waste diversion, Mountain View can look into implementing financial incentives. For example, the city can use a PAYT system instead of assigning trash carts based on household size. The city can also look into more outreach services to increase diversion and participation rates.

City of Palo Alto. The City of Palo Alto is currently compliant with SB 1383. It seems they are on their way to meet the bill's diversion goals in the future because they are aiming for almost no waste to be burned or buried by 2021 and recognize that zero waste is not possible without addressing organic waste (City of Palo Alto, 2019a). A smart practice that Palo Alto can pursue is removing the term, "Food Waste" from their platforms. 
County and City of San Francisco. San Francisco is likely to exceed SB 1383

requirements due to their zero waste program; they have already reached an $80 \%$ waste diversion rate (EPA, 2019b) and have mandated organic waste diversion efforts (SF Environment, 2019a). San Francisco already has extensive public outreach and education programs including door to door outreach in multiple languages, detailed information on their websites, and so on (SF Environment, 2019c). There are no recommendations for the city at this time.

City of San Jose. San Jose actively diverts organic waste from landfills and is on its way to meeting SB 1383 goals; they have already accomplished a 74\% diversion rate (including nonorganic waste diversion) (EPA, 2019c). The city just needs to ensure that their organic waste is being diverted at high rates as well. Although San Jose does not collect food scraps separately, the city may still benefit from changing the term "Food Waste" to "Food Scraps" on all their platforms to help make residents see food scraps as a resource. It may encourage residents to waste less or use food scraps for other purposes such as composting. This tactic may have minimal effect but it will cost the city close to nothing to implement. It is not recommended that San Jose pursue higher tipping fees for organic waste at landfills because the city's waste system separates organics from other waste before MSW is taken to landfills (City of San Jose, n.d.a).

City of Santa Clara. Santa Clara is currently implementing a pilot RFSP in response to SB 1383 (City of Santa Clara, 2019). It is recommended that public outreach be expanded to keep residents involved in the program and to increase waste diversion. The city can try outreach via community or block leaders, individuals that will teach their neighbors why it is important to divert food scraps and how to compost at home. Should Santa Clara expand their program in 2021, there should be a policy that the food scraps sides of residents' split carts be utilized (use should be required, not voluntary). 
City of Sunnyvale. Sunnyvale started a RFSP in response to SB 1383 and their adopted Zero Waste plan. Their pilot had good results; a high participation rate of 73\% and high food capture rate of 62\% (City of Sunnyvale, 2019a). There are no recommendations for Sunnyvale at this time. In the future, if participation rates are not satisfactory, the city should consider partnering with community organizations for outreach and education.

All the cities analyzed in this report technically are compliant with SB 1383, even though Morgan Hill has minimal efforts. This is because SB 1383 is flexible and at this time, rules and regulations are still being finalized (CalRecycle, 2019b). SB 1383 has state requirements (CalRecycle, 2019b); it is not clear at this time what the specific requirements for cities are. For example, was it intended that individual cities also meet organic waste diversion goals of a 50\% reduction in 2020 and a 75\% reduction by 2025 compared to their 2014 levels? Do cities have their 2014 organic waste measures? Will counties' organic waste be measured and regulated in lieu of cities? (This may be problematic, as some cities dump their waste in other counties). These questions may be answered in 2020. In 2020 when CalRecycle and CARB measure progress in organic waste diversion targets, CalRecycle may add requirements or even propose revisions to the bill (CalRecycle, 2019b). It seems that specific municipality requirements may only be implemented if the state organic waste diversion targets are not met.

\section{Limitations}

Ideally in a Process Evaluation, discussions and point of view are taken from stakeholders through meetings, surveys, or interviews (Sylvia \& Sylvia, 2012). In this report stakeholders included residents, haulers, city employees, and other local government personnel. Minimal information was taken through communication with stakeholders (only program details from various cities’ Departments of the Environment and haulers). It is possible that interviewing 
stakeholders would have provided insight on why cities chose the options they did, or why they were experiencing the challenges and barriers they had. Regarding smart practices, they should be considered when current practices are ineffective or detrimental, and when the risks of a smart practice match or are lower than the risks of alternatives (Bardach \& Patashnik, 2016).

Another point to consider when reviewing this evaluation is that a city that claims to divert $75 \%$ (or any percentage) of all waste does not mean the city is successfully diverting or reducing $75 \%$ of their organic waste. While cities should be applauded for their waste diversion goals, efforts, and feats, cities should take care to have measures or indicators in place to monitor how much organic waste is being diverted to ensure SB 1383 compliance, and to help reduce SLCPs. Many cities in this report had waste diversion goals and results, but the percentage of organic waste being diverted was unclear. 


\section{CONCLUSION}

Cities in this report are complying with SB 1383 by having split garbage cans (used for garbage and food waste) or having food scraps added to their compost, organics, or yard trimmings carts. All three cities that use split carts (Milpitas, Santa Clara, and Sunnyvale) turn their food scraps into animal feed. Cities that combine food with other organics turn their food scraps into compost and energy. The majority of the cities has a zero waste plan, which further fuels organic waste diversion efforts. Separate fees for food scrapping services are not used. With the exception of San Francisco, cities do not use fines to motivate participation and proper sorting.

The most supported and commonly used smart practices are (1) financial incentives (PAYT systems), (2) public outreach and education, (3) having formal organic waste diversion policies, and (4) having a pre-existing infrastructure or program (such as a yard waste program). Higher landfill tipping costs for non-organic waste is also a heavily supported smart practice; however most cities in this report did not have landfills within their boundaries, so this smart practice was usually not applicable. All but one city in this report use only one or a few haulers. San Jose has four haulers (Romanow, 2017), which created difficulty in implementing their RFSP due to different operational approaches, and not being able to come to an agreement on a citywide program (A. Lowrie, personal communication, February 15, 2019). Therefore it is recommended that, if feasible, cities attempting a RFSP limit their number of haulers to one or two. Starting with a pilot program is also recommended; Palo Alto and San Jose implemented pilot programs and found that it was not feasible for their cities. Because they started with pilot programs instead of starting with city wide changes in curbside services, time, effort, and money were saved. 
At this time, it is not clear how municipalities’ organic waste will be regulated, or how they will ensure that diversion percentages are meeting state requirements. Although enforcement and fines are expected to begin in 2022, it is not clear what will constitute a penalty. This information and expectations were expected to be finalized in early 2019. However, in preparation for future regulation, municipalities should begin to track the percentages of organic waste diverted, and if they have not done already, start planning their organic waste diversion program/efforts. The requirements of SB 1383 (regarding organic waste diversion) are not restrictive and give municipalities flexibility. Based on SB 1383's flexibility, the fact that municipalities have begun to successfully divert significant amounts of organic waste (Alameda County, San Francisco, San Jose, and Sunnyvale), and that food is an easy item to keep out of the landfill, California is in a good position to meet SB 1383 goals.

\section{Future Research}

It is not clear how cities and residents will be impacted financially. Some research demonstrated that RFSPs or similar composting programs saved cities money; research also showed that such programs were not sustainable due to costs. Additionally, some people believe that such a program will impact cities and residents negatively. Future research should make financial impacts of RFSPs and curbside composting more clear. Future research should also help determine whether separating organics at the source (by residents) or at the facility is more efficient and, potentially, more affordable. One argument for separating at the source is that residents will see how much food they are wasting. It might also be beneficial for cities to determine whether Mountain View’s multiple food scrapping programs led to significantly increased organic waste diversion compared to similar cities with only one food scraps program. 
Municipalities can see whether having one food scrapping program is efficient or if having a multiple approach model is best. 


\section{REFERENCES}

Alameda County Waste Management Authority. (n.d.). Recycling rules Alameda County: City of Livermore. Retrieved March 1, 2019 from http://www.recyclingrulesac.org/city/city-of-livermore/

Anderson, P., \& Liss, G. (2010). Expanding diversion of food scraps and soiled paper. Biocycle, 51(9), 20-22, 24.

Associated Press. (2018). Ick factor: NYC so far turns up nose at food-scrap recycling. Daily Mail. Retrieved from https://www.dailymail.co.uk/wires/ap/article-6249687/Ick-factor-NYC-far-turns-nosefood-scrap-recycling.html

Attachment E: Domestic refuse collection. (2017). Retrieved March 2, 2019 from http://www.greenwasteofpaloalto.com/sites/greenwasteofpaloalto.com/files/R1\%207-12017.pdf

Bardach, E. \& Patashnik, E. M. (2016). A practical guide for policy analysis: The eightfold path to more effective problem solving. Thousand Oaks, CA: CQ Press.

California Air Resources Board. (2018). Reducing short-lived climate pollutants in California. Retrieved January 9, 2018 from https://www.arb.ca.gov/cc/shortlived/shortlived.htm

California Legislative Information (2016). SB-1383 short-lived climate pollutants: Methane emissions: Dairy and livestock: Organic waste: Landfills. Retrieved October 3, 2018 from https://leginfo.legislature.ca.gov/faces/billNavClient.xhtml?bill_id=201520160SB1383

CalRecycle. (2018a). Funding. Retrieved from 
https://www.calrecycle.ca.gov/organics/food/funding

CalRecycle. (2018b). FY 2018-19 food waste prevention and rescue grant program.

Retrieved from

https://www.calrecycle.ca.gov/climate/grantsloans/foodwaste/fy201819

CalRecycle. (2018c). Mandatory commercial organics recycling. Retrieved from

https://www.calrecycle.ca.gov/recycle/commercial/organics

CalRecycle. (2019a). Alternative daily cover (ADC). Retrieved from

https://www.calrecycle.ca.gov/lgcentral/basics/adcbasic

CalRecycle. (2019b). Short-lived climate pollutants (SLCP): Organic waste methane emissions

reductions. Retrieved from

https://www.calrecycle.ca.gov/Climate/SLCP/

Cerda, A., Artola, A., Font, X., Barrena, R., Gea, T., \& Sanchez, A. (2018). Composting of food wastes: Status and challenges. Bioresource Technology, 248, 57-67.

doi: 10.1016/j.biortech.2017.06.133

City of Cupertino. (2017). Zero waste policy: City of Cupertino: Resolution no. 17-xxx

Retrieved from https://www.cupertino.org/home/showdocument?id=19101

City of Cupertino. (2019a). Compost. Retrieved from

https://www.cupertino.org/our-city/departments/environment-

sustainability/waste/compost

City of Cupertino. (2019b). Curbside composting. Retrieved from

https://www.cupertino.org/our-city/departments/environment-

sustainability/waste/compost/curbside-composting

City of Cupertino. (2019c). Garbage and recycling. Retrieved from 
https://www.cupertino.org/our-city/departments/environment-sustainability/waste

City of Morgan Hill. (n.d.a). Garbage and recycling. Retrieved from

https://www.morgan-hill.ca.gov/106/Garbage-Recycling

City of Morgan Hill. (n.d.b). Utility services. Retrieved from

https://www.morgan-hill.ca.gov/845/Utility-Services

City of Mountain View. (n.d.a). Curbside food scraps program and multi-family pilot. Retrieved January 29, 2019 from

https://www.mountainview.gov/depts/pw/includefood/includefood/default.asp

City of Mountain View. (n.d.b). Homes [1-8 units] split-carts. Retrieved from

https:/www.mountainview.gov/depts/pw/recycling/garbage/residents/carts/default.asp

City of Palo Alto. (2014). City of Palo Alto: Finance committee staff report (ID\# 4541).

Retrieved January 29, 2019 from

https://www.cityofpaloalto.org/civicax/filebank/documents/42450

City of Palo Alto. (2018). Zero waste plan. Retrieved from

https://www.cityofpaloalto.org/civicax/filebank/documents/66620

City of Palo Alto. (2019a). Progress report. Retrieved January 29, 2019 from

https://www.cityofpaloalto.org/gov/depts/pwd/zerowaste/about/progress.asp

City of Palo Alto. (2019b). What goes where tools. Retrieved January 29. 2019 from

https://www.cityofpaloalto.org/gov/depts/pwd/zerowaste/whatgoeswhere/toolkit.asp

City of San Jose. (n.d.a). Recycling processing. Retrieved from

http://www.sanjoseca.gov/index.aspx?NID=2267

City of San Jose. (n.d.b) What goes where. Retrieved from

http://www.sanjoseca.gov/index.aspx?nid=1545\#food 
City of Santa Clara. (n.d.a). 2019 Garbage/recycling collection schedule. Retrieved from http://santaclaraca.gov/home/showdocument?id=62670

City of Santa Clara. (n.d.b). Pilot residential food scraps recycling program survey \#2. Retrieved February 17. 2019 from http://santaclaraca.gov/home/showdocument?id=62676

City of Santa Clara. (n.d.c). Pilot residential food scraps recycling program survey results. Retrieved February 17. 2019 from http://santaclaraca.gov/home/showdocument?id=56273

City of Santa Clara. (2018). Table A: City of Santa Clara rates for collection and disposal of garbage, refuse, clean green, recycling, annual clean-up campaign, and household hazardous waste services. Retrieved from http://santaclaraca.gov/home/showdocument?id=58334

City of Santa Clara. (2019). Pilot residential food scrap recycling program. Retrieved March 9, 2019 from http://santaclaraca.gov/government/departments/public-works/environmentalprograms/residential-garbage-recycling/residential-food-scrap-pilot-recycling-program

City of Sunnyvale. (n.d.). City of Sunnyvale fiscal year 2018/19 utility fee schedule. Retrieved from https://sunnyvale.ca.gov/civicax/filebank/blobdload.aspx?blobid=23726

City of Sunnyvale. (2019a). Foodcycle. Retrieved from https://sunnyvale.ca.gov/property/recycling/scrap.htm

City of Sunnyvale. (2019b). Frequently asked questions about foodcycle. Retrieved from https://sunnyvale.ca.gov/civicax/filebank/blobdload.aspx?blobid=23667

City of Sunnyvale. (2019c). Recycling and garbage. Retrieved from 


\section{https://sunnyvale.ca.gov/property/recycling/default.htm}

Cohen, S. (2018). Using the food we waste in New York City. The Earth Institute, Columbia University. Retrieved from https://blogs.ei.columbia.edu/2018/10/08/using-food-waste-new-york-city/

Desilver, D. (2016). Perceptions and realities of recycling vary widely place to place. Pew Research Center. Retrieved November 12, 2018 from http://www.pewresearch.org/fact-tank/2016/10/07/perceptions-and-realities-of-recyclingvary-widely-from-place-to-place/

Earth Talk. (2018). Why is recycling not mandatory in all U.S. cities? Thought Co. Retrieved from https://www.thoughtco.com/why-recycling-not-mandatory-all-cities-1204150

Environmental Protection Agency. (2017a). How communities have defined zero waste. Retrieved from https://www.epa.gov/transforming-waste-tool/how-communities-have-defined-zero-waste

Environmental Protection Agency. (2017b). Sustainable food management: Food recovery hierarchy. Retrieved from https://www.epa.gov/sustainable-management-food/food-recovery-hierarchy

Environmental Protection Agency. (2019a). Wasted food programs and resources across the United States. Retrieved from https://www.epa.gov/sustainable-management-food/wasted-food-programs-andresources-across-united-states

Environmental Protection Agency. (2019b). Zero waste case study: San Francisco. Retrieved from https://www.epa.gov/transforming-waste-tool/zero-waste-case-study-san-francisco Environmental Protection Agency. (2019c). Zero waste case study: San Jose. Retrieved from 
https://www.epa.gov/transforming-waste-tool/zero-waste-case-study-san-jose

E/The Environmental Magazine. (2010). Why no national recycling law in the U.S.? Business Ethics: The Magazine of Corporate Responsibility. Retrieved from http://business-ethics.com/2010/11/21/why-no-national-recycling-law-in-the-u-s/

Freeman, J., \& Skumatz, L. (2011a). Accelerating implementation of food scrap programs. Biocycle, 52(8), 28-30.

Freeman, J., \& Skumatz, L. (2011b). Food scraps programs in the United States. Biocycle, 52(7), $18-21$.

Geislar, S. (2017). The new norms of food waste at the curb: Evidence-based policy tools to address benefits and barriers. Waste Management, 68, 571-580.

Goodyear, S. (2018). A brief history of household recycling. The Atlantic City Lab. Retrieved from https://www.citylab.com/city-makers-connections/recycling/

Google Maps. (2019). [Google’s online portal for directions and maps]. Retrieved from https://www.google.com/maps

GreenWaste.[Greenwaste Recovery]. (2016, August 1). Yard trimmings collection process. [Video File]. Retrieved March 3, 2019 from https://www.youtube.com/watch?v=YWZ_Qwhismw\&feature=youtu.be

GreenWaste. (2019). Material recovery facility (MRF). Retrieved from http://www.greenwaste.com/about-us/material-recovery-facility-mrf

Gunders, D. \& Bloom, J. (2017). Wasted: How America is losing up to 40 percent of its food from farm to fork to landfill. New York, NY: National Resources Defense Council, Inc.

Jenkins, R. R., Martinez, S. A., Palmer, K., \& Podolsky, M. J. (2003). The determinants of household recycling: A material-specific analysis of recycling program features and unit 
pricing. Journal of Environmental Economics and Management, 45, 294-318.

Johnston, M. (2017). Testing household food scraps collection methods. BioCycle, 58, 28-30. Retrieved from http://search.proquest.com.libaccess.sjlibrary.org/docview/1862879254?accountid=10361

Layzer, J. A. \& Schulman, A. (2014). Municipal curbside compostables collection: What works and why? Cambridge, MA: Department of Urban Studies and Planning, Massachusetts Institute of Technology. Available at https://dusp.mit.edu/sites/dusp.mit.edu/files/attachments/project/Municipal\%20Curbside \%20Compostables\%20Collection\%20\%20What\%20Works\%20and\%20Why.pdf

Li, Z., Lu, H., Ren, L., \& He, L. (2013). Experimental and modeling approaches for food waste composting: A review. Chemosphere, 93, 1247-1257.

Livermore Recycles. (2018a). [Livermore Recycles homepage]. Retrieved from https://livermorerecycles.org/

Livermore Recycles. (2018b). Organics: These items go in the green cart. Retrieved from https://livermorerecycles.org/organics/

Livermore Sanitation. (2019). Service menu for residents of single-family homes. Retrieved from https://www.livermoresanitation.com/residential/residential-services/

MacBride, S. (2015). Source separated organics in large New York City apartment buildings. BioCycle, 56, 67-70.

Milpitas Sanitation. (n.d.a). Garbage/food scraps split cart sizes and rates. Retrieved from https://www.milpitassanitation.com/wp-content/uploads/2019/01/MSI-2019-SFD-REScart-sizes-and-rate.pdf

Milpitas Sanitation. (n.d.b). What happens to your food scraps? Retrieved from 
https://www.milpitassanitation.com/wp-content/uploads/2017/07/MSI-what-happens-toyour-Food-Scraps-2017.pdf

Milpitas Sanitation. (2019a). Provider of recyclables, organics, and garbage collection services. Retrieved from https://www.milpitassanitation.com/

Milpitas Sanitation. (2019b). Provider of recyclables, organics, and garbage collection services: Collection cart program.

Retrieved from https://www.milpitassanitation.com/residential/cartprogram/

Milpitas Sanitation. (2019c). Provider of recyclables, organics, and garbage collection services: Setout tips and frequently asked questions. Retrieved from https://www.milpitassanitation.com/faqs/

Milpitas Sanitation. (2019d). Provider of recyclables, organics, and garbage collection services: Publications \& Resources. Retrieved from https://www.milpitassanitation.com/residential/resources/

Montgomery, T. (n.d.). The San Jose residential food scraps pilot program [Power Point slides]. Retrieved January 29, 2019 from http://swanacal.com/symposium_2016/Track\%202/2_SWANA\%20Track2\%20Garden\% 20City\%20Pilot\%20Revised.pdf

Nelson, J., Jarland, J., \& Katsaros, S. (2015). Growing a food scrap composting infrastructure in Illinois. BioCycle, 56(3), 52-56. Retrieved from http://search.proquest.com.libaccess.sjlibrary.org/docview/1671667953?accountid=10361

Pollans, L.B., Krones, J.S., \& Ben-Joseph, E. (2017). Patterns in municipal food scrap programming in mid-size U.S. cities. Resources, Conservation, \& Recycling, 125, 308314. Retrieved from 
https://www.sciencedirect.com/science/article/pii/S0921344917301829?via\%3Dihub

Recology. (n.d.a). Mission and vision. Retrieved from

https://www.recology.com/about-us/\#where-we-serve

Recology. (n.d.b). Rates. Retrieved from

https://www.recology.com/recology-san-francisco/rates/

Recology. (n.d.c). Recology organics. Retrieved from

https://www.recology.com/organics/\#our-products

Recology. (n.d.d). Recology sunset scavenger \& recology golden gate schedule a: Residential and apartment refuse rates effective July 1, 2018. Retrieved February 15, 2019 from https://sfpublicworks.org/sites/default/files/Schedule\%20A\%20-

\%20Residential\%20\%26\%20Apartment\%20-2018_07.pdf

Recology. (n.d.e). South valley organics. Retrieved from https://www.recology.com/recology-south-valley/south-valley-organics/

Recology. (n.d.f). Welcome to recology: Recology: A world without waste. https://www.recology.com/

Recology. (n.d.g). We're updating your services. Retrieved from https://www.recology.com/recology-san-francisco/san-francisco-service-updates/\#/info

Recycle Stuff. (2018). Recycle stuff.org. Retrieved from http://www.recyclestuff.org/

Residential Rate Schedule. (n.d.). Retrieved from

https://www.cupertino.org/home/showdocument?id=23004

Rethink Food Waste Through Economics and Data. (2019). 27 Solutions to food waste.

Retrieved from https://www.refed.com/?sort=economic-value-per-ton

Romanow, K. (2016, January 12). Council agenda: 01-12-16 item: 7.1. City of San Jose Council 
Meeting, January 12, 2016. Retrieved January 29, 2019 from

http://sanjose.granicus.com/MetaViewer.php?view_id=\&event_id=2118\&meta_id=5509 34

Romanow, K. (2017, February 15).T\&E agenda: 03/06/2017 item: d(1).City of San Jose Council Meeting, March 06, 2017. Retrieved January 29, 2019 from http://sanjose.granicus.com/MetaViewer.php?meta_id=619657

SF Environment. (n.d.a). Mayor Lee announces San Francisco reaches 80 percent landfill waste diversion, leads all cities in Northern America. Retrieved February 15, 2019 from https://sfenvironment.org/news/press-release/mayor-lee-announces-san-franciscoreaches-80-percent-landfill-waste-diversion-leads-all-cities-in-north-america

SF Environment. (n.d.b). SF recycles. Retrieved from https://www.sfrecycles.org/

SF Environment. (2019a). Myths about recycling in San Francisco. Retrieved from https://sfenvironment.org/myths-about-recycling-in-sf

SF Environment. (2019b). Zero waste. Retrieved from https://sfenvironment.org/zero-waste-in-SF-is-recycling-composting-and-reuse\#city

SF Environment. (2019c). Zero waste: Frequently asked questions. Retrieved from https://sfenvironment.org/zero-waste-faqs

Silva, A., Rosano, M., Stocker, L., \& Gorissen, L. (2017). From waste to sustainable materials management: Three case studies of the transition journey. Waste Management, 61, 547557. Retrieved from https://doi.org/10.1016/j.wasman.2016.11.038

Specialty Solid Waste \& Recycling (2017). History. Retrieved from https://sswr.com/about/

Sustainable Alternative Feed Enterprises. (2016). SAFE quick facts. Author. Retrieved from 


\section{https://www.forktofeed.com/facts}

Sylvia, R., \& Sylvia, K. M. (2012). Program planning and evaluation for the public manager. Long Grove, IL: Waveland Press, INC.

Turmelle, L. (2018). Reducing food waste is focus of federal legislation, Blumenthal says. New Haven Register. Retrieved from https://www.nhregister.com/business/article/Reducing-food-waste-is-focus-of-federal13331001.php

United States Census Bureau. (n.d.a). Quick facts: Cupertino city, California. Retrieved from https://www.census.gov/quickfacts/fact/table/cupertinocitycalifornia\#

United States Census Bureau. (n.d.b). Quick facts: Livermore city, California. Retrieved from https://www.census.gov/quickfacts/fact/table/livermorecitycalifornia/PST045217

United States Census Bureau. (n.d.c). Quick facts: Milpitas city, California. Retrieved from https://www.census.gov/quickfacts/milpitascitycalifornia

United States Census Bureau. (n.d.d). Quick facts: Morgan Hill city, California. Retrieved from https://www.census.gov/quickfacts/fact/table/morganhillcitycalifornia/RHI125217

United States Census Bureau. (n.d.e). Quick facts: Mountain View city, California. Retrieved from https://www.census.gov/quickfacts/mountainviewcitycalifornia

United States Census Bureau. (n.d.f). Quick facts: Palo Alto city, California. Retrieved from https://www.census.gov/quickfacts/fact/table/paloaltocitycalifornia,US/PST045217

United States Census Bureau. (n.d.g). Quick facts: San Francisco city, California. Retrieved from https://www.census.gov/quickfacts/fact/table/sanfranciscocitycalifornia,US/PST045217 United States Census Bureau. (n.d.h). Quick facts: San Jose city, California. Retrieved from https://www.census.gov/quickfacts/fact/table/sanjosecitycalifornia,US/PST045217 
United States Census Bureau. (n.d.i). Quick facts: Santa Clara city, California. Retrieved from https://www.census.gov/quickfacts/fact/table/santaclaracitycalifornia/PST045217

United States Census Bureau. (n.d.j). Quick facts: Sunnyvale city, California. Retrieved from https://www.census.gov/quickfacts/sunnyvalecitycalifornia

University of California Cooperative Extension. (2019). Composting education. Retrieved from http://cesantaclara.ucanr.edu/Home_Composting_Education/

Vaz. N. M. (2015). Are you going to eat that?: A new wave of mandatory recycling has Massachusetts and other New England states paving the way toward feasible food waste diversion and a new player in alternative energy. Villanova Environmental Law Journal, 26, 193-214.

Yepsen, R. (2015). Residential food waste collection in the U.S. BioCycle, 56, 53-63. Retrieved from http://search.proquest.com.libaccess.sjlibrary.org/docview/1648958674?accountid=10361

Z-Best Composting. (n.d.). About us. Retrieved from https://www.zankerrecycling.com/zbest/about-us/ 
Appendix A

EPA Food Recovery Hierarchy

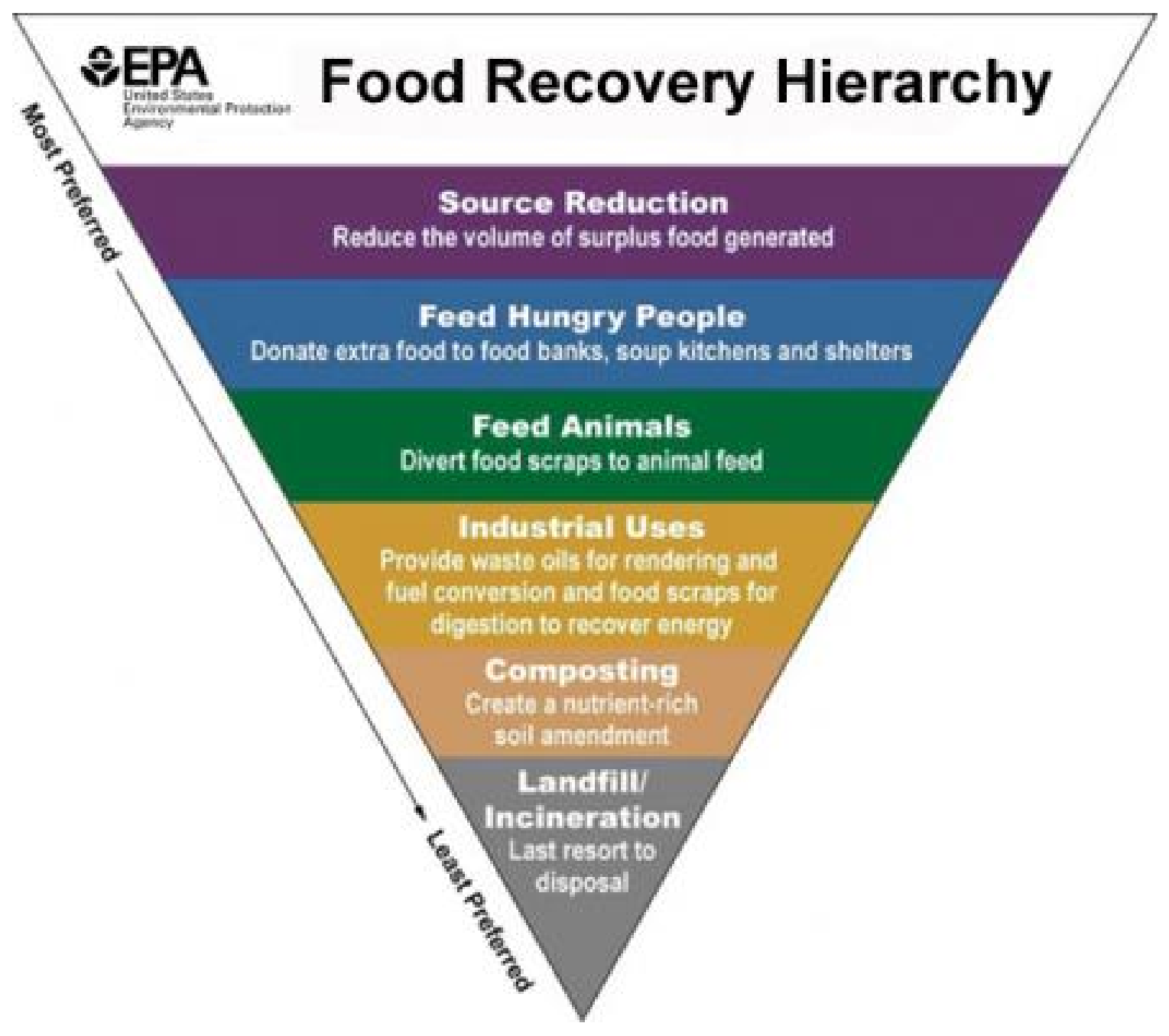

Source: EPA (2017b) 
Appendix B

City of Milpitas Garbage Cart Rates

\section{GARBAGE/FOOD SCRAPS SPLIT CART SIZES \& RATES}

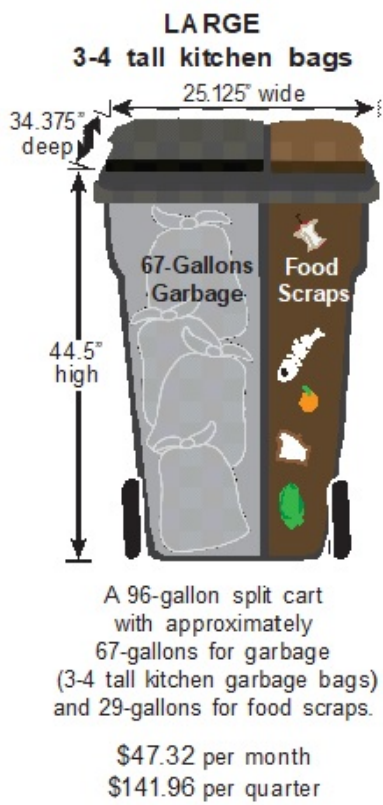

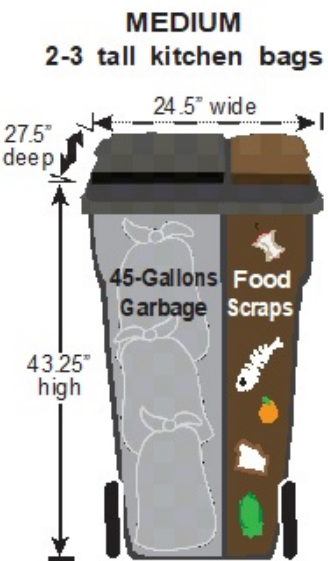

A 64-gallon split cart with approximately 45-gallons for garbage (2-3 tall kitchen garbage bags) and 19-gallons for food scraps.

$\$ 41.19$ per month $\$ 123.57$ per quarter

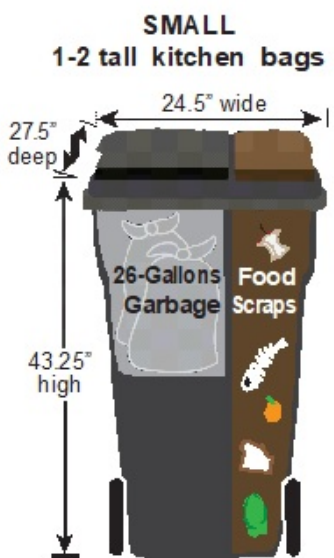

A 64-gallon split cart with an insert for approximately 26-gallons for garbage (1-2tall kitchen garbage bags) and 19-gallons for food scraps.

$\$ 35.02$ per month $\$ 105.06$ per quarter

Senior Rate for SMALL cart $\$ 17.51$ per month $\$ 52.53$ per quarter
EXTRA SMALL

1 tall kitchen bag

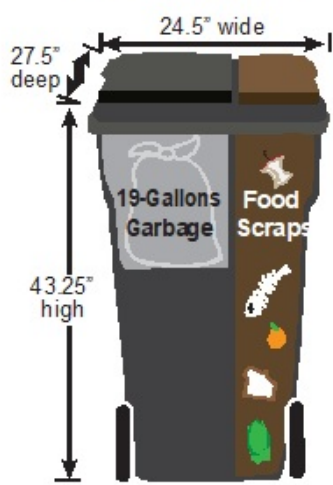

A 64-gallon split cart with an insert for approximately 19-gallon s for garbage (1 tall kitchen garbage bag) and 19-gallons for food scraps.

$\$ 32.22$ per month $\$ 96.66$ per quarter

Senior Rate for EXTRASMALL cart $\$ 16.11$ per month $\$ 48.33$ per quarter

Source: Milpitas Sanitation (n.d.a) 